\title{
Climate change, resilience, and population dynamics in Pakistan: A case study of the 2010 floods in Mianwali District
}

\author{
Zeba Sathar \\ Population Council \\ Muhammad Khalil \\ Population Council \\ Sabahat Hussain \\ Population Council \\ Maqsood Sadiq \\ Population Council
}

Kiren Khan

Follow this and additional works at: https://knowledgecommons.popcouncil.org/departments_sbsr-pgy

Part of the Demography, Population, and Ecology Commons, Environmental Public Health Commons, Family, Life Course, and Society Commons, International Public Health Commons, and the Place and Environment Commons

How does access to this work benefit you? Let us know!

\section{Recommended Citation}

Sathar, Zeba, Muhammad Khalil, Sabahat Hussain, Maqsood Sadiq, and Kiren Khan. 2018. "Climate change, resilience, and population dynamics in Pakistan: A case study of the 2010 floods in Mianwali District." Islamabad: Population Council. 
RESEARCH TO

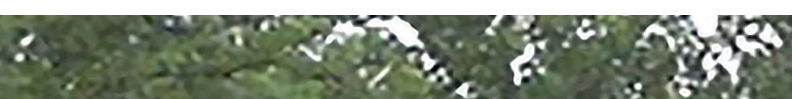

CLIMAT CHANGE RÉSILIENCE ANOA POPULATION DYNAMICS IN PAKISTAN

A CASE STUDY OF THE 2010 FLOODS IN MIANWALI DISTRIC.:
FILL CRITICAL

EVIDENCE GAPS

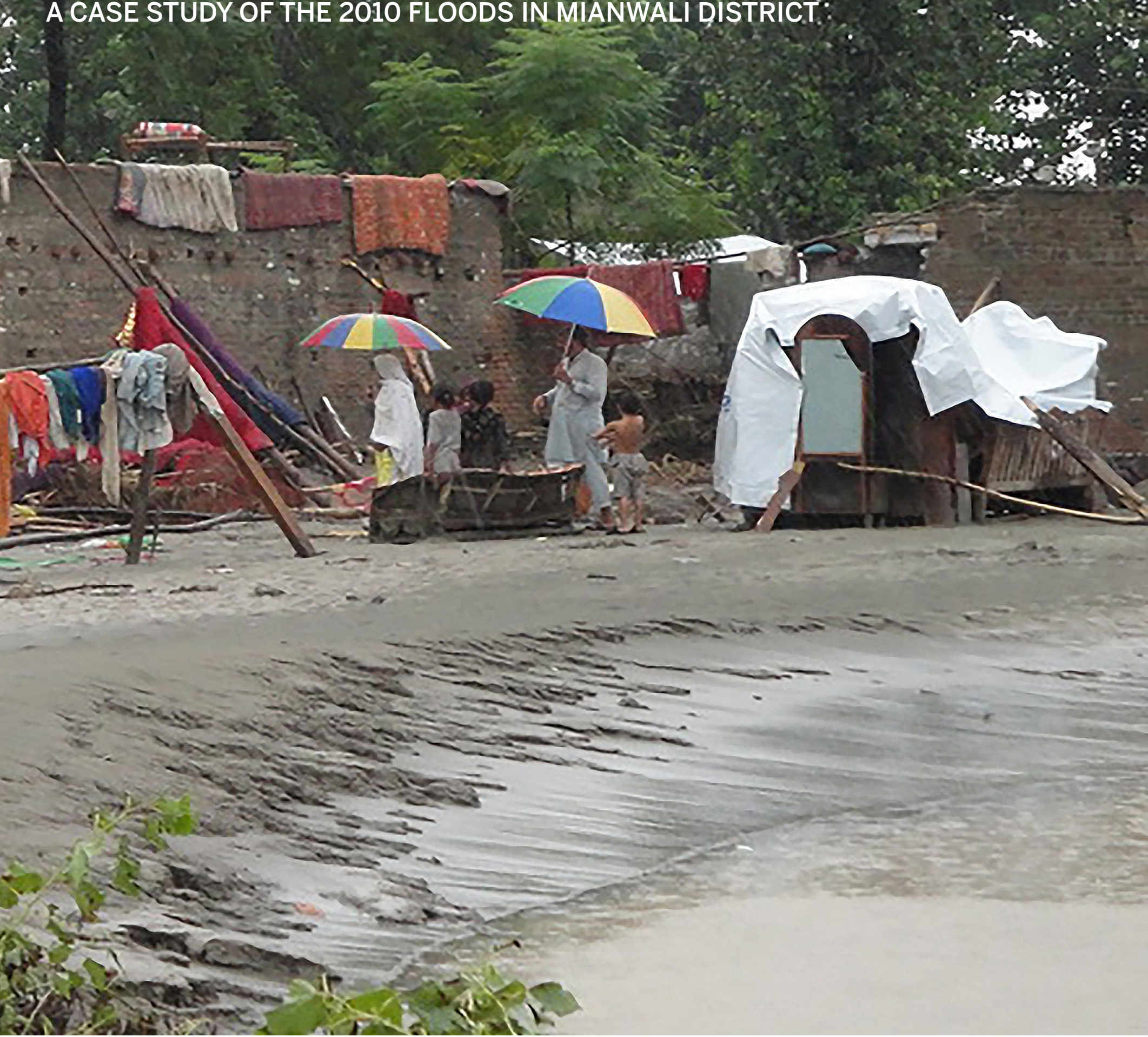

af 
The Population Council is prioritizing research to strengthen the evidence on resilience among those who are vulnerable to environmental stressors. This research is designed to fill evidence gaps and generate the evidence decision-makers need to develop and implement effective programs and policies.

popcouncil.org/research/climate-change-vulnerabilityand-resilience

\section{For information on partnership and funding opportunities, contact:}

Jessie Pinchoff, jpinchoff@popcouncil.org

Suggested citation: Sathar, Zeba, A., Muhammad Khalil, Sabahat Hussain, Maqsood Sadiq, and Kiren Khan. 2018. "Climate Change, Resilience, and Population Dynamics in Pakistan: A Case Study of the 2010 Floods in Mianwali District." Pakistan: Population Council.

Photos: Population Council Staff Islamabad

(c) 2018 The Population Council, Inc 


\section{In 2010, Pakistan experienced massive flooding that went on}

uninterrupted for more than eight weeks, and seriously affected more than $\mathbf{2 0}$ million people. This study explores the effects of the floods on one of the most adversely affected districts, Mianwali, in Punjab province.

A multidisciplinary approach is taken to analyze available demographic and geospatial data for a deeper understanding of the communitylevel vulnerability to the 2010 floods, to identify demographic changes potentially associated with the floods, and to describe the implications for building resilience in regions at high risk of large-scale flood events. We focus on four areas pertaining to resilience:

1. Movements and migration processes

2. Shifts in poverty levels and living conditions

3. Changes in livelihood activities

4. Health-seeking behavior, particularly fertility-related processes

This study highlights the need to include demographic and health information in the analysis of natural disasters. We see this as the beginning of a research agenda that can capitalize on data from the Population Census, the Agriculture Census, and other sources to build a national overview of how climate change is affecting people, livelihoods, and health, and vice versa, in Pakistan. 


\section{ACKNOWLEDGMENTS}

The authors gratefully acknowledge the support provided by colleagues at the Population Council offices in Washington, DC, New York, and Islamabad. We particularly thank Dr. Karen Hardee for providing the funding for this study and the encouragement to pursue the RP4 agenda in Pakistan. Consultations with Dr. Hardee, Dr. Sajeda Amin, and Dr. Jessie Pinchoff helped us refine our approach. We thank Dr. Mark Montgomery for suggesting sources of data for the study after our initial presentation in July 2017. Colleagues in Islamabad, especially Dr. Ali Mir, Dr. Gul Rashida, Seemin Ashfaq, Iram Kamran, Rehan Niazi, and Tahira Parveen, provided invaluable advice and guidance. 


\section{TABLE OF CONTENTS}

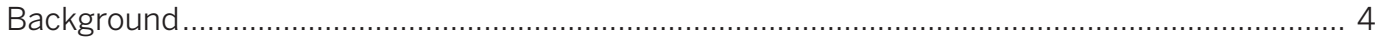

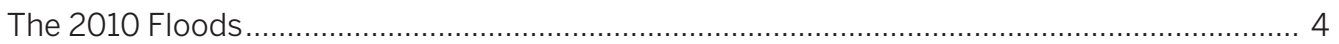

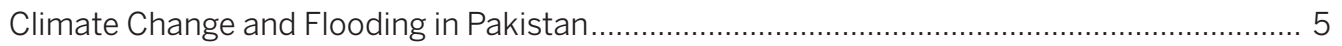

Effects of Climate Change on Individuals, Families, and Communities .............................. 6

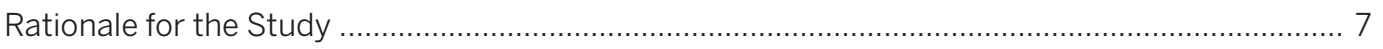

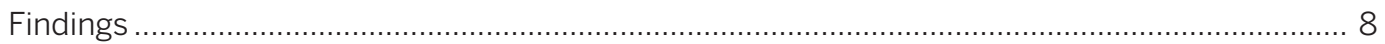

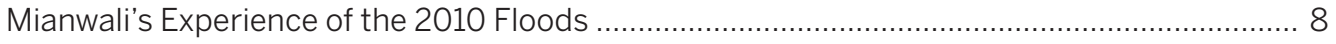

Evidence of Migration As an Adaptive Response of Mianwali's Population After the 2010

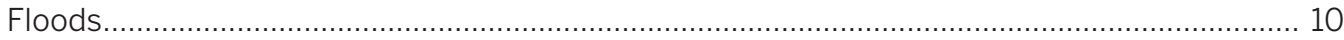

Changes in the Economic Behavior of Mianwali's Population That May Be Associated with the 2010 Floods, and Implications for Future Resilience .............................................. 16

Poverty Levels and Living Conditions in Mianwali After the 2010 Floods ............................. 19

Changes in Behavior with Respect to Health (Especially Reproductive Health) and

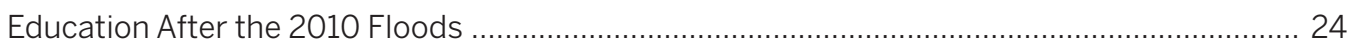

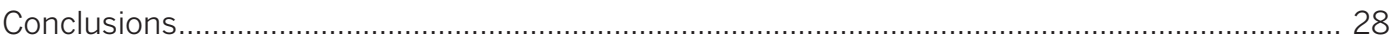

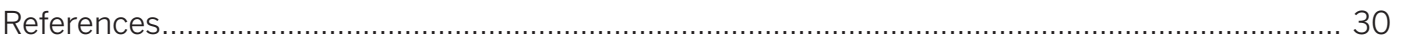


BACKGROUND

\section{THE 2010 FLOODS}

In 2010, Pakistan experienced massive flooding that left one-fifth of the country under water. Although Pakistan is prone to flooding, the scale of the 2010 floods was unprecedented. The flooding was induced by temperature rise in the north that led to glacier melting, accompanied by nine of the heaviest rains recorded in the country within a 24-hour period. These extreme events drastically increased the flow of the Indus River, swelling it to 40 times its normal volume, which caused serious flooding in the Indus Plain across the major provinces. The floods went on uninterrupted for more than eight weeks, inundating an area of 132,000 square kilometers (51,000 square miles). Approximately 2,000 people were killed, over 1.9 million houses were destroyed, and more than 20 million people were seriously affected. Called a "tsunami in slow motion" by the UN Secretary General at the time (Guardian 2010), it was the largest disaster ever recorded in terms of the affected population, area covered, and number of households damaged (Najam-u-Din 2010; Solberg 2010). Figure 1 shows the extent of the damage and adverse impact of the 2010 floods.

FIGURE 1. Districts Affected by the 2010 Floods in Pakistan

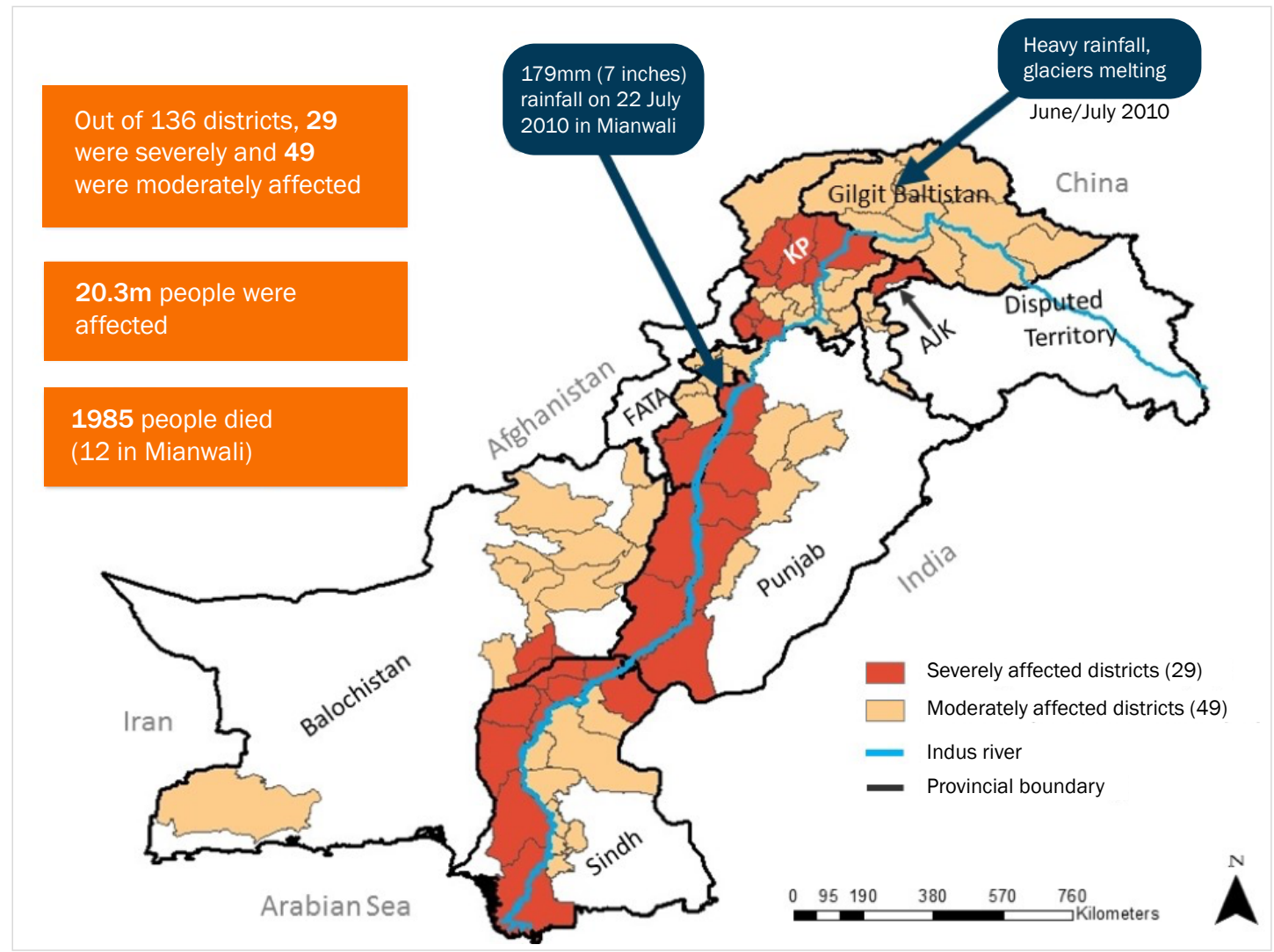

SOURCE: UN Office for the Coordination of Humanitarian Affairs (UNOCHA), NDMA, and SUPARCO. 
Statistics from the immediate aftermath of the 2010 floods are clear, yet less is known about the longer-term effects on population dynamics, living patterns, economic status, and health outcomes. The incidence and impact of floods in Pakistan in terms of natural assets, infrastructure, and topography and terrain, are well documented. However, studies in Pakistan largely do not address issues of human vulnerabilities, resilience, and adaptation, which should inform strategies for keeping the population safer when contending with future floods.

\section{CLIMATE CHANGE AND FLOODING IN PAKISTAN}

According to Global Climate Risk Index 2017, Pakistan is the seventh most seriously affected country in terms of climate change (Kreft et al. 2016). This ranking is based on a death toll of 523.1 lives per year over the last 20 years and economic losses amounting to US $\$ 3.8$ billion from 141 extreme weather events like floods, glacial lake outburst floods, heat waves, and storms. The country is also now ranked as the fifth most populous nation in the world, according to the 2017 Population and Housing Census (PBS 2017).

Projections up to 2100 by the World Bank-Climate Change Knowledge Portal (CCKP) indicate that the expected temperature increase in Pakistan is higher than the expected global average increase (World Bank 2018). The general trend is an increasing number of heavy rainfall events ${ }^{1}$ and increasing average temperatures over the last 70 years. The data show that temperature increase in the northern part of the country is higher than in the south: in the northern areas, the melting of the Hindu Kush, Karakoram, and Himalayan glaciers due to rising temperatures has created over 3,000 glacial lakes, of which 33 are considered prone to glacial lake outburst floods. Millions of cubic meters of water can pour into the Indus River and its tributaries in just a few hours, putting more than 7.1 million people at risk. Pakistani National Climate Change Policy 2012 predicts that the largest national climate change threats are the considerable increase in the frequency and intensity of extreme weather events, coupled with erratic monsoon rains causing frequent and intense floods and droughts. The Hindu Kush-Karakoram-Himalayan glaciers are projected to recede, threatening huge water inflows into the Indus Basin (Ministry of Climate Change 2012).

Despite the increasing risks, there are generally only limited early-warning systems or disaster management and preparedness plans to protect communities. Erosion by deforestation exacerbates the risks, and safety infrastructure, such as protective walls and spillways, are largely lacking (UNDP 2016).

The melting of the glaciers in the north, combined with peaks in rainfall, have contributed to a higher frequency and greater intensity of floods in the country in recent years. The 2010 floods are notable for their severity (Federal Flood Commission 2015). 


\section{EFFECTS OF CLIMATE CHANGE ON INDIVIDUALS, FAMILIES, AND COMMUNITIES}

Although climate change and its adverse impacts are widely acknowledged in the developing world (Nelson et al. 2009), its intersections with and effects on individuals, families, communities, and countries over time are relatively less studied. Brooks (2003) argues the importance of viewing vulnerability and resilience to climate change more holistically, by paying attention to the social and demographic aspects that mediate the outcome of this change, such as poverty, housing quality, sources of livelihood, and demographic behaviors. Studies of demographic and economic responses to climate-induced adverse events are scant, including for Pakistan.

Both demography and economics can elucidate vulnerability to climate change and capture changes related to adaptive capacity and resilience. Dodman et al. (2009) suggest that resilience is a process that enables the ability to cope with added shocks and stresses, and also addresses the myriad challenges that constrain lives and livelihoods and facilitates more general improvements to the quality of human lives. Resilience is shaped by individual, household, and community access to a range of rights, resources, and assets; better-off households can frequently buy their way out of risk with better infrastructure or by moving to safer locations, whereas most low-income groups are tied to the location and dangerous sites for their livelihoods, homes, assets, social networks, and culture. While studies of

climate impacts do include economic effects, these studies tend to overlook crucial demographic characteristics, such as household size, living arrangements, fertility, and age structures, among others (Bartlett 2008; Patt et al. 2009), that may be crucial for gauging trends in adaptive responses, and for projecting the future vulnerability and resilience of populations exposed to risks. 


\section{RATIONALE FOR THE STUDY}

This study explores the effects of an adverse weather event in Pakistan, and the demographic processes contributing both to the vulnerability of the populations at risk, and their adaptive responses and resilience. The 2010 floods provide a natural experiment in which to study the impact and aftermath of the floods in one of the most adversely affected districts, Mianwali District in Punjab Province. Figure 2 shows the trend of increasing rainfall in the district between 1945 and 2015.

FIGURE 2. Trends in Average Monthly Temperature (Centigrade) and Monthly Rainfall (Millimeters) for Mianwali, 1945-2015

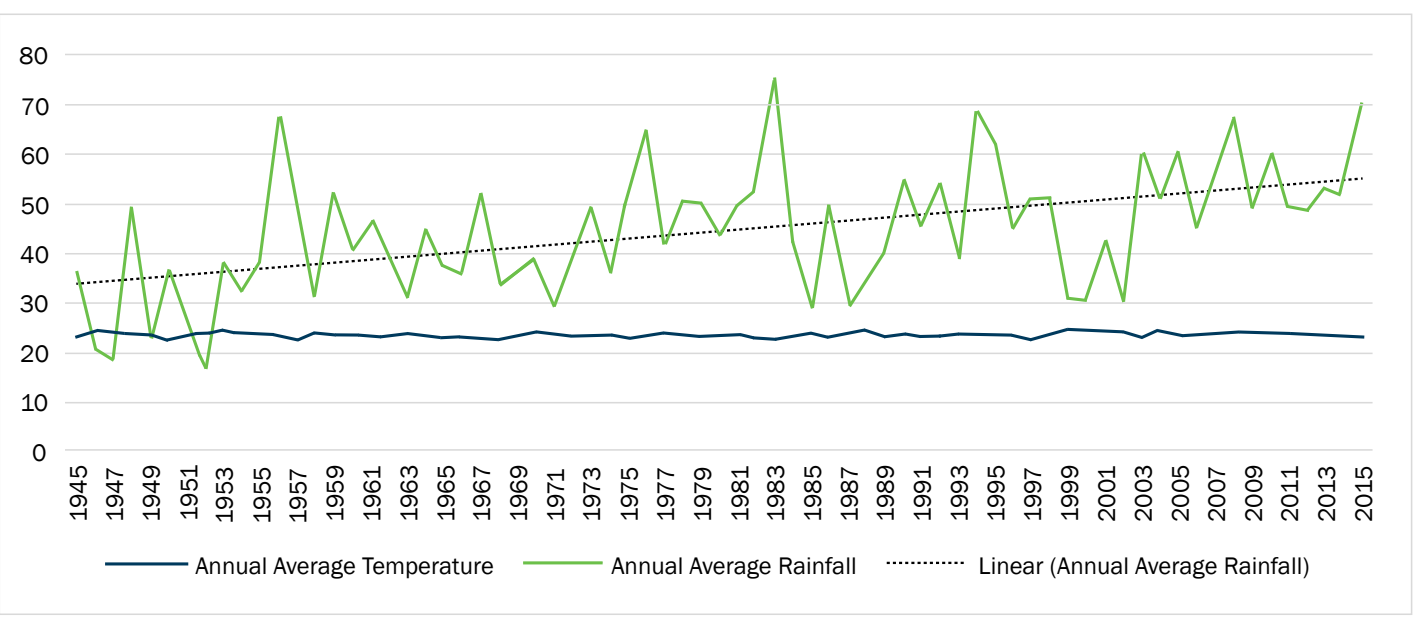

SOURCE: World Bank Climate Change Knowledge Portal (CCKP).

In this study, we take a multidisciplinary approach to analyze available demographic and geospatial data for a deeper understanding of the community-level vulnerability to the 2010 floods, to identify demographic changes potentially associated with the floods, and to describe the implications for building resilience in regions at high risk of large-scale flood events. This study focuses on four areas pertaining to resilience: movements and migration processes; shifts in poverty levels and living conditions; changes in livelihood activities; and health-seeking behavior, particularly fertilityrelated processes. These are some of the dimensions that we expect to both reflect and shape the responses of communities in terms of "bouncing back" and "building back stronger" in the "medium term."

Analysis is organized around answering four questions:

1. Is there evidence that migration may be part of the adaptive response of Mianwali's population after the 2010 floods?

2. Are there any changes in the economic behavior of Mianwali's population that may be associated with the 2010 floods, and what do they imply for future resilience?

3. Have poverty levels and living conditions improved or deteriorated in Mianwali since the 2010 floods?

4. Has behavior changed with respect to health (especially reproductive health) and education since the 2010 floods? 
In addition to the outcomes identified, another value of this study is that it demonstrates how available population statistics and geospatial data can be overlaid to visualize flood events and map the population at risk to produce a fuller picture of the medium- and long-term impact of climate change, as well as the vulnerability and adaptive responses of affected populations. In addition, this approach highlights that climatic and demographic processes are dynamic and linked, and the understanding of these interactions is critical to inform strategies aimed at managing future climate risks. This study is intended to expand the discussion on climate-change adaptation in Pakistan and elsewhere, and to highlight the need for including a demographic lens through which a more comprehensive understanding of the potential impacts of devastating flood events can be achieved.

\section{FINDINGS}

\section{MIANWALI'S EXPERIENCE OF THE 2010 FLOODS}

Mianwali is one of the poorest districts in Punjab province, ranking 29th out of 36 districts on the Multi-Dimensional Poverty Index. Mianwali straddles the Indus River at the northern end of the Indus Plain, which is in an intense heat zone that is affected by any rise in temperature. Surrounded by mountains in the west and north, and large areas of the plains along the banks of the Indus, Mianwali District is historically prone to floods and inundation during the monsoon season. Mianwali is comprised of three tehsils (subdistricts), including Isa Khel, which makes up the northern and western part of the district, Mianwali in the east, and Piplan in the south, as shown in Figure 3.

FIGURE 3: Key Topographic Features of Mianwali District, Punjab Province

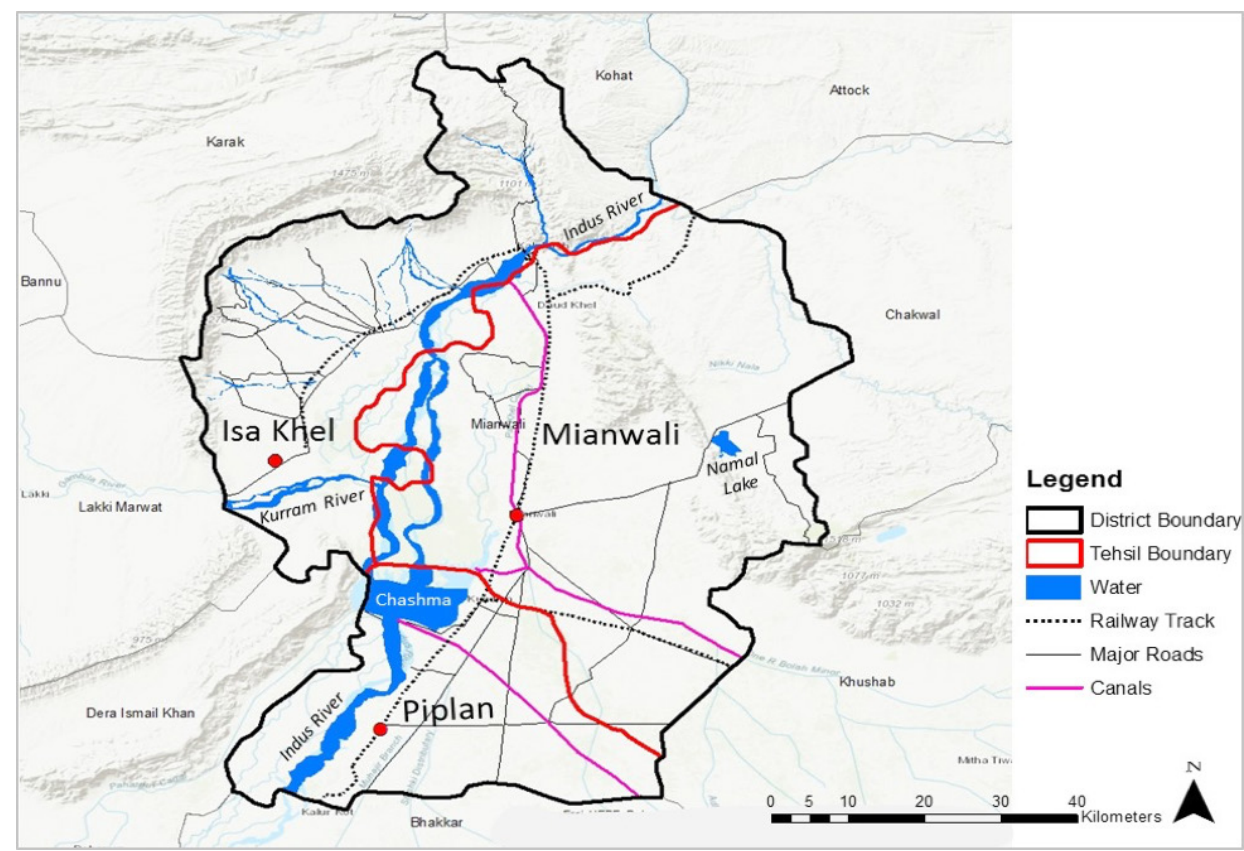


TABLE 1: Proportion of Population, Housing Structures, and Area in Punjab Province, and in Mianwali District and its Tehsils, Impacted by the 2010 Floods

\begin{tabular}{|l|c|c|c|c|c|c|}
\hline & \multicolumn{2}{|c|}{ Population } & \multicolumn{2}{c|}{ Houses } & \multicolumn{2}{c|}{ Area } \\
\hline Region & $\begin{array}{c}\text { Total } \\
\text { (Thousand } \\
\text { Persons) }\end{array}$ & $\begin{array}{c}\text { \% Population } \\
\text { Impacted }\end{array}$ & $\begin{array}{c}\text { Total } \\
\text { (Thousand } \\
\text { Structures) }\end{array}$ & $\begin{array}{c}\text { \% Houses } \\
\text { Damaged }\end{array}$ & $\begin{array}{c}\text { Total } \\
\text { (Sq. km) }\end{array}$ & $\begin{array}{c}\text { \% Land } \\
\text { Flooded }\end{array}$ \\
\hline Punjab Province & 93,682 & 6.4 & 14,870 & 3.3 & 205,344 & 29 \\
\hline Mianwali District & 1,309 & 50.2 & 219 & 8.6 & 5,840 & 21.9 \\
\hline Isa Khel Tehsil & 330 & 98.9 & 55 & 21.6 & 1,863 & 23.9 \\
\hline Mianwali Tehsil & 645 & 34.4 & 110 & 5.3 & 2,689 & 21.0 \\
\hline Piplan Tehsil & 334 & 35.5 & 54 & 0.7 & 1,288 & 20.8 \\
\hline
\end{tabular}

SOURCE: Government of Punjab, Punjab Development Statistics 2010 and NDMA 2011. NOTE: 1 sq. km. = .39 sq. mi.

Mianwali District registered record rains in 2010: the maximum rainfall of 179 millimeters (7 inches) was noted on July 22 (SUPARCO 2010). In July and August 2010, the district received 482 millimeters (19 inches) of rain -the highest rainfall in 50 years. Mianwali had an estimated population of 1.3 million at the time, of which 672, 322-more than half-were affected by the floods, with 12 flood-related deaths reported (Government of Punjab 2010; OCHA 2011). The district was one of the most severely affected in the entire country, incurring substantial infrastructural and health-related losses. The damage incurred in Mianwali comprised 6 percent of the total estimated affected population in the province and 29 percent of the affected geographic area in Punjab (Government of Punjab 2010; NDMA 2011).

Table 1 shows that of the three tehsils in the district, Isa Khel was most devastated by the floods, particularly in terms of total population affected. Although all three tehsils had similar proportions of area covered by floodwaters, almost the entire population of Isa Khel was affected, compared to about a third of the population in the other two tehsils. This could be in part because Isa Khel was physically more exposed to the flood hazard, not only as the northern entry point of the district in the path of the Indus, but also because of its low elevation bordered by hills in the west, which increased its exposure to flash floods. The population of Isa Khel was living in the areas that got flooded, whereas the population of the other two tehsils either lived in areas that were not flood affected or were able to move to safer areas.

The maps in Figure 4 show the courses of the Kurram and Indus rivers across Mianwali in 2008 and 2011, i.e., before and after the floods. The 2011 map depicts the extent of the spread of flood waters in the months following the peak of the crisis and confirms that a large population around the river would have had to shift away from their homes and farms at least temporarily to avoid high water levels. The intense flooding spread for 2-13 kilometers (1-8 miles) on the western bank (Isa Khel) and 2-8 kilometers (1-5 miles) on the eastern bank (Mianwali) of the Indus. The map for 2016 shows that the floods did not just pose immediate risks to the population but also introduced new waterways and topographic changes, characterized by the slight shifting of the Indus riverbed from west to east and a broadening of the banks of the river. This had direct implications, particularly for usage of land and cropping patterns. The 2016 map points to longer-term movement of population settlements away from the river toward the eastern bank. 
FIGURE 4: River Courses and Settlements in Mianwali Before and After the 2010 Floods

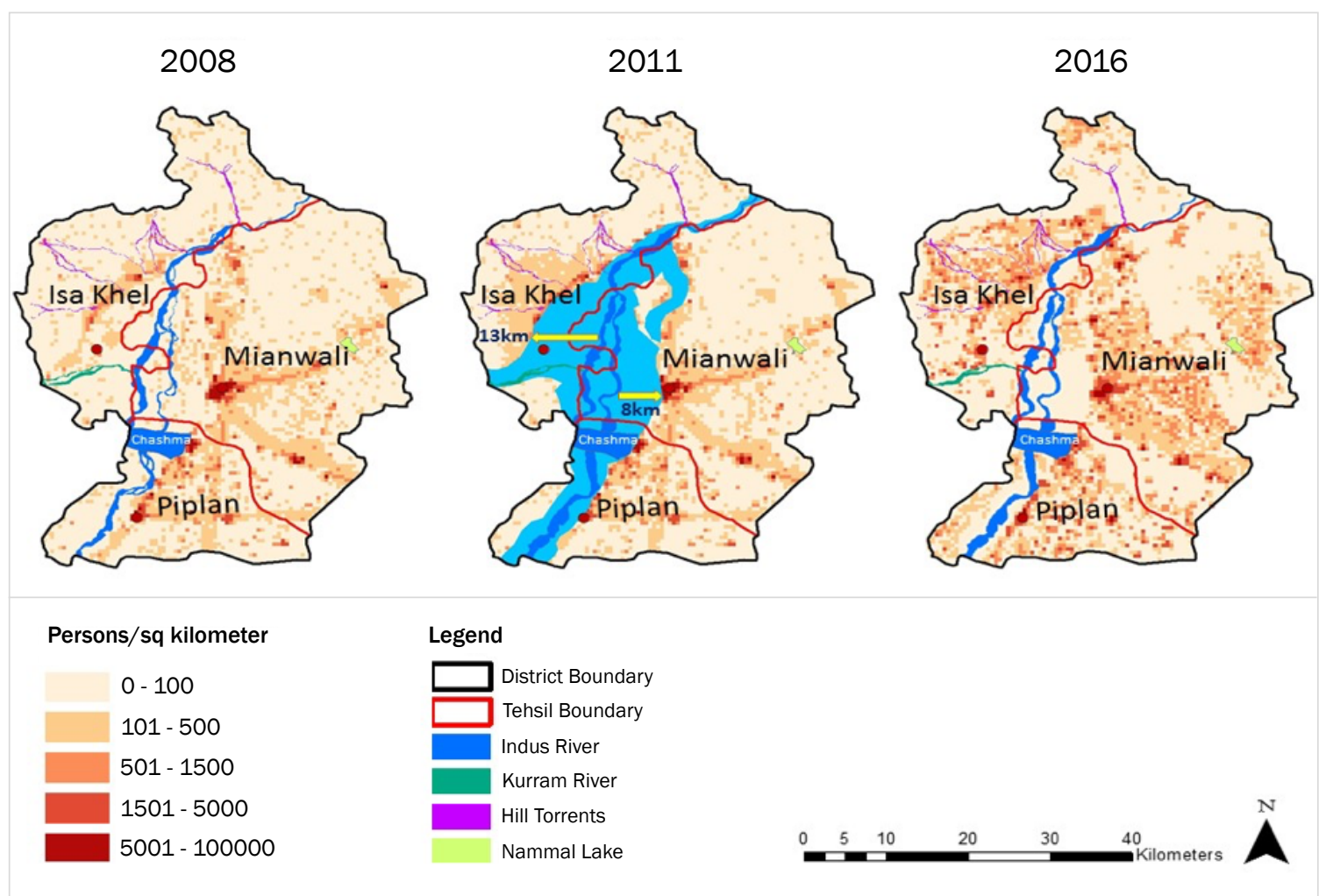

SOURCE: LandScan Population Dataset 2008, 2011, 2016 and Landsat.

We address the four questions posed above, in the discussion of the study's rationale, by looking at Mianwali District, with a focus on Isa Khel, to assess whether the floods were associated with or have been followed by any changes in the spread of population, socioeconomic well-being and livelihoods, and other health and social indicators.

\section{EVIDENCE OF MIGRATION AS AN ADAPTIVE RESPONSE OF MIANWALI'S POPULATION AFTER THE 2010 FLOODS}

Environmental factors are among many variables driving migration. Some forms of environmentally induced migration may be adaptive, while other forms of forced migration and population displacement may indicate a failure of the social-ecological system to adapt (Warner 2011). In settings similar to Mianwali that experience climate-induced disasters, displacement is a common though undesirable response. In Bangladesh, due to land degradation and scarcity, those who were poor and dependent on agriculture became less able to make a living. Frequent storms, floods, and droughts compound the problem. Largely due to environmentally induced scarcities, 12-17 million Bangladeshis have moved to India since the second World War, and half a million moved internally (Swain 1996; Homer-Dixon 1999; Lee 2001). Cain (1981) found higher mobility (in terms of households changing between landholding size categories) in Bangladesh than in India and suggested that this was because floods caused distress sale of lands and other assets at a loss in Bangladesh. This is supported by Orr et al. (1992) who found that 29 percent of households sold or mortgaged land after the 1988 flood 
and reported increased downward mobility after the flood with a high proportion (43 percent) of land loss since inheritance in the three years after the flood.

Predictions in Pakistan prior to the 2010 floods suggested that climate change would play a role in increasing rural-to-urban migration, which constitutes 40 percent of total internal migration in the country (Arif 2005). Mueller, Gray, and Kosec (2014) proposed that while rising temperatures increase ruralurban migration, and thereby lower the dependence on agriculture, floods do not significantly influence long-term migration in Pakistan. Although liquidity constraints may be responsible for people's reluctance or inability to migrate permanently (Bryan et al. 2014; Cattaneo and Peri 2016), guaranteed availability of humanitarian aid in response to climatic extremes such as floods and storms may also be responsible for slowing down the migration response to floods (Strömberg 2007; Looney 2012) and for facilitating farmers' return to their ancestral location. However, a major World Health Organization (WHO) study does point out increased deprivation in flood-affected districts, particularly in communities living close to the riverbeds, increasing the possibility of a trend of rural-to-urban, intra-provincial, and inter-provincial migration in search of livelihoods (Asian Development Bank and World Bank 2010).

We know that the 2010 floods forced seven million people across the country to leave their homes at least temporarily (Najam-u-Din 2010). According to a WHO survey conducted in the 29 most severely affected districts, close to 90 percent of households were forced to move for at least two weeks after the floods, with over half having to live at a camp for internally displaced people (IDPS) at some point. Approximately 17 percent were forced to move away for longer durations (WHO and Ministry of Health 2011). It is believed that most of the displaced population returned to their home areas as soon as the floodwaters receded, usually within around a month, although the duration of displacement was generally longer in Sindh Province.

Irrespective of the duration of displacement, many of those who returned faced problems similar to those confronted by conflict IDPs, due to the destruction of houses and communication, health, and education infrastructure, as well as diminished livelihood prospects, in the short term at least, as the floods had extensively damaged crops and livestock (Najam-u-Din 2010). Farmers generally tend to resume agricultural activities in their regions of origin after floods. However, as floods become more frequent, many will not have the means to continue farming on silted land and invest in inputs like seeds and fertilizers to attain agricultural profits (Arai 2012). With floods recurring more often, many farming households may have shifted toward nonfarming livelihood activities or diversified their sources of income (Food Security Cluster Pakistan 2013). Because of limited alternative economic opportunities in rural areas, many frequent flood victims may migrate in search of nonfarm income sources in urban areas (Salik et al. 2017).

Although no major climate-induced migration flows have been recorded or discussed thus far in Pakistan, floods, and climate change more broadly, are likely to have contributed significantly to the large-scale spatial changes including ruralto-urban and cross-province migration reflected in the 2017 census. Unfortunately, 
TABLE 2: Change in Average Annual Growth Rates and Household Size in Punjab Province, and in Mianwali District and Its Tehsils

\begin{tabular}{|l|c|c|c|c|c|c|}
\hline & \multicolumn{3}{|c|}{ Population Growth (\%) } & \multicolumn{3}{c|}{ Household Size } \\
\hline \multicolumn{1}{|c|}{ Region } & $\begin{array}{c}\text { AAGR } \\
1981-1998\end{array}$ & $\begin{array}{c}\text { AAGR } \\
1998-2017\end{array}$ & $2017 / 1998$ & 2008 & 2011 & Change \\
\hline Punjab Province & 2.60 & 2.13 & .81 & 6.5 & $6.3^{* *}$ & -0.2 \\
\hline Mianwali District & 2.35 & 2.02 & .85 & 6.8 & $6.1^{* *}$ & -0.7 \\
\hline Isa Khel Tehsil & 2.83 & 2.00 & .70 & 7.2 & $5.9^{* *}$ & -1.3 \\
\hline Mianwali Tehsil & 2.09 & 1.92 & .91 & 6.5 & $6.1^{* *}$ & -0.4 \\
\hline Piplan Tehsil & 2.45 & 2.16 & .88 & 7.1 & $6.4^{* *}$ & -0.7 \\
\hline
\end{tabular}

Differences in household size between 2008 and 2011 are significant at $p<0.01$ and are labeled **.

Differences in household size in Punjab Province and Mianwali District in 2011 are significant at $p<0.10$.

SOURCE: Population Census Reports and Punjab MICS 2008 and 2011.

neither the census data nor any other surveys can provide data about inter-district migration or the movement from rural to urban areas. But preliminary census results do reflect long-term growth rates beyond natural increase in certain areas and certainly more rapid growth in urban than in rural areas.

In the absence of direct sources, we utilize the data available particularly at the tehsil level, which are the Punjab Multiple Indicator Cluster Survey (MICS) datasets, to measure short-term changes between 2008 and 2011, and longer-term changes in demographic profiles between the two national censuses in 1998 and 2017.

Faster deceleration in population growth: Comparing data from the 2017 census to the 1998 census, we find many dramatic long-term changes. While growth rates have declined in Punjab province from 2.6 to 2.1 percent, in Mianwali District, growth rates have declined beyond provincial averages to 2.02 percent.

Table 2 depicts population growth in the three tehsils from 1998-2017. While growth is lowest in Mianwali and highest in Piplan, in terms of decline in growth since 1981-98, Table 2 reveals our most adversely flood-affected tehsil of Isa Khel to have the largest decline, with Intercensal growth rates down from 2.83 for 1981-98 to 2.0 percent in the 1998-2017 period. Compared to Isa Khel, growth rates of the other two tehsils have not changed as dramatically, hinting that the population of Isa Khel may have reacted to the recent devastating floods and their aftermath. However, causality cannot be established with the available data. In fact, the more urban tehsil of Mianwali shows the least change in growth rates, most likely reflecting an influx of migration from adjoining Isa Khel and Piplan. 
FIGURE 5: Changes in Mouza Population Sizes in Mianwali District between 1998 and 2017

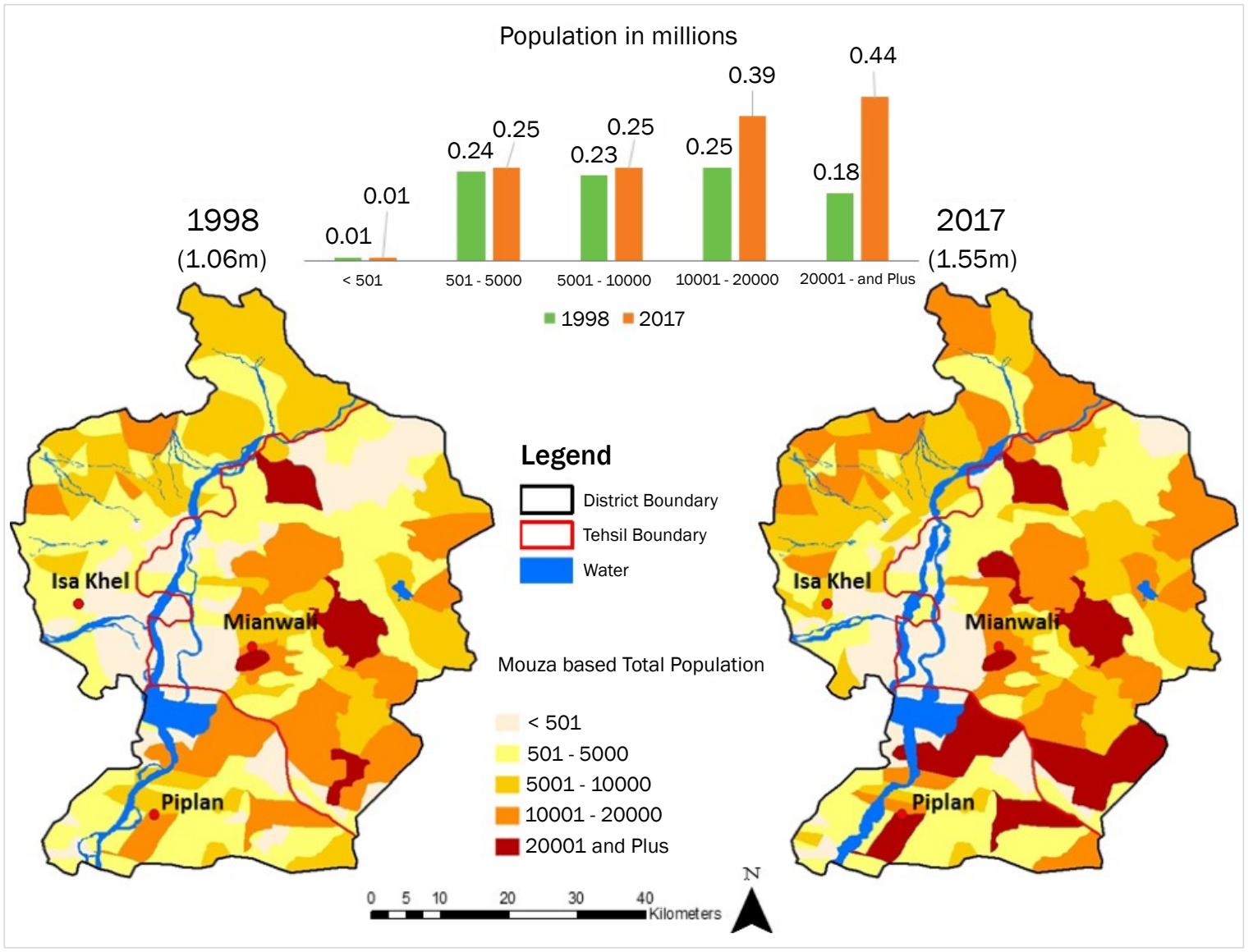

SOURCE: Population Census 1998 and 2017.

Increasing urbanization: The census data allow us to present a more granular perspective on changes in population densities and distribution across "mouza," the smallest administrative unit, over a 19-year period. There are hints that the population, which until now was rural, assumed greater intensity of migration to more urbanized agglomerations within Mianwali District. According to recommendations by the UN prior to the 2010 census rounds, as well as researchers within Pakistan, mouzas representing 10,000 persons and above can be classified as urban (Arif and Ibrahim 1998; UN 2005). The proportion of Mianwali's population living in such mouzas has risen to 83 percent compared to 43 percent in 1998, while the share living in mouzas with less than 10,000 persons has increased only marginally (Figure 5). In fact, most of the population growth that has occurred since the last census has taken place in the larger settlements. Most of these larger towns are in Mianwali and Piplan tehsils and not in Isa Khel, which was most affected by the floods.

Decline in household size: Using data from the MICS 2008 and comparing to 2011, we find further evidence of dramatic population changes. Household size has declined sharply in Isa Khel, with a reduction of 1.3 persons, as compared to a smaller though still sizable decline in Mianwali tehsil of 0.4 persons (Figure 6). We posit the likelihood that these changes are reflective of both rural to urban migration and with a pronounced change, especially in Isa Khel, happening as recently as in the post-flood period. 
FIGURE 6: Changes in Household Size in Punjab Province, and in Mianwali District and Its Tehsils, 2008 and 2011

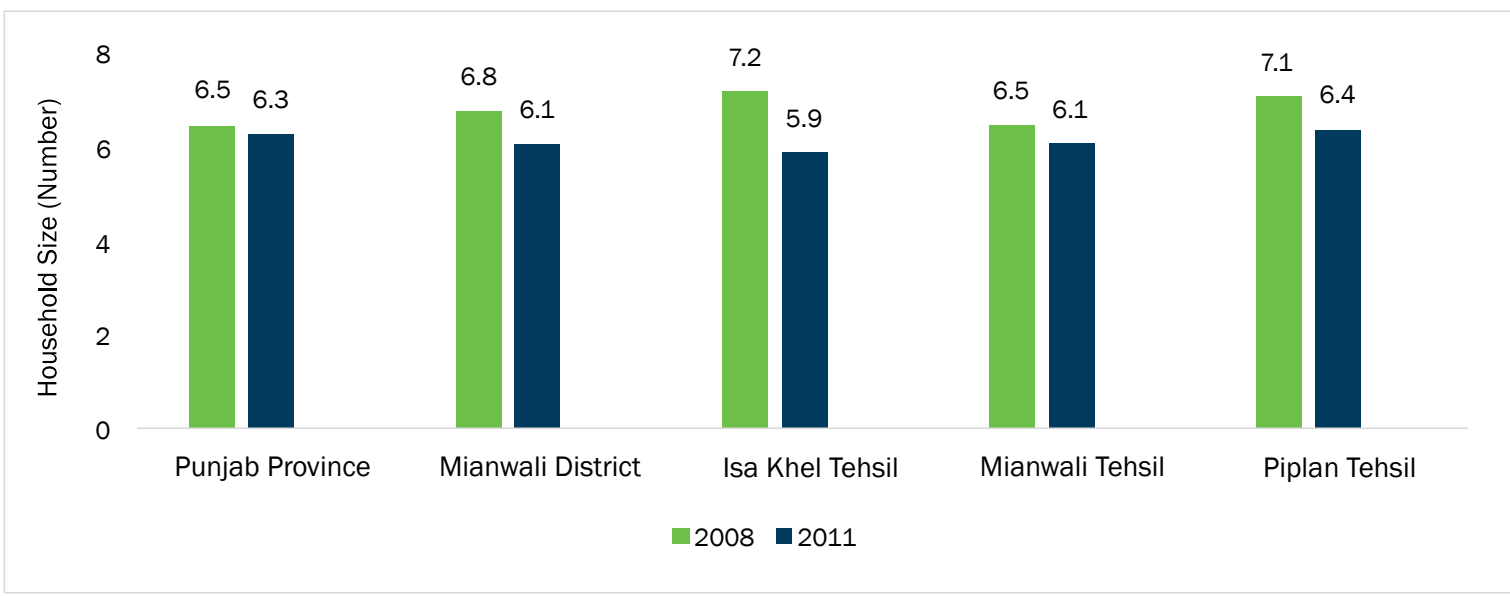

SOURCE: Punjab MICS 2008 and 2011.

TABLE 3: Change in Age Structure of Households in Punjab Province, and in Mianwali District and its Tehsils, 2008 and 2011

\begin{tabular}{|l|c|c|c|c|c|c|c|c|c|c|}
\hline & \multicolumn{2}{|c|}{$<5$} & \multicolumn{2}{c|}{$5-14$} & \multicolumn{2}{c|}{$15-60$} & \multicolumn{2}{c|}{$61 /+$} & \multicolumn{2}{c|}{ Household Size } \\
\hline Region & 2008 & 2011 & 2008 & 2011 & 2008 & 2011 & 2008 & 2011 & 2008 & 2011 \\
\hline $\begin{array}{l}\text { Punjab } \\
\text { Province }\end{array}$ & 0.8 & 0.8 & 1.6 & 1.6 & 3.7 & 3.5 & 0.4 & 0.4 & 6.5 & 6.3 \\
\hline $\begin{array}{l}\text { Mianwali } \\
\text { District }\end{array}$ & 0.8 & 0.6 & 1.7 & 1.6 & 4.0 & 3.5 & 0.4 & 0.4 & 6.8 & 6.1 \\
\hline $\begin{array}{l}\text { Isa Khel } \\
\text { Tehsil }\end{array}$ & 1.0 & 0.5 & 1.7 & 1.6 & 4.1 & 3.5 & 0.4 & 0.3 & 7.2 & 5.9 \\
\hline $\begin{array}{l}\text { Mianwali } \\
\text { Tehsil }\end{array}$ & 0.7 & 0.6 & 1.7 & 1.5 & 3.8 & 3.5 & 0.3 & 0.4 & 6.5 & 6.1 \\
\hline $\begin{array}{l}\text { Piplan } \\
\text { Tehsil }\end{array}$ & 0.8 & 0.7 & 1.7 & 1.7 & 4.1 & 3.6 & 0.4 & 0.4 & 7.1 & 6.4 \\
\hline
\end{tabular}

SOURCE: Punjab MICS 2008 and 2011.

Changes in household composition: We do not have fertility data at the tehsil level from the MICS, but we can deduce the latest trends from the breakdown of numbers of children under age 5. Table 3 shows that while in 2008 the average number of children under age 5 in Isa Khel was 1.0, much higher than the number for the other two tehsils, this drops to 0.5 in 2011. In contrast, the relative declines in numbers of children under age 5 in Piplan and Mianwali are very slight. The more rapid fertility decline in Isa Khel may also reflect that, with substantial displacement and out-migration from the tehsil, the relatively younger couples have moved more in search of better opportunities for children, leaving behind older families.

As further evidence of migration within the district, there is a decline in household members of all ages (reflecting total family migration) and particularly those in the working ages of 15-60 years away from tehsil Isa Khel. This is further reinforced by the decline in joint households at a much greater pace in Isa Khel compared to Mianwali tehsil, the most likely destination for the migration. Table 3 shows that the population of Mianwali tehsil has grown older, largely because of in-migration for work. 
FIGURE 7: Number of Registered International Emigrants from Mianwali District, 1981-2014

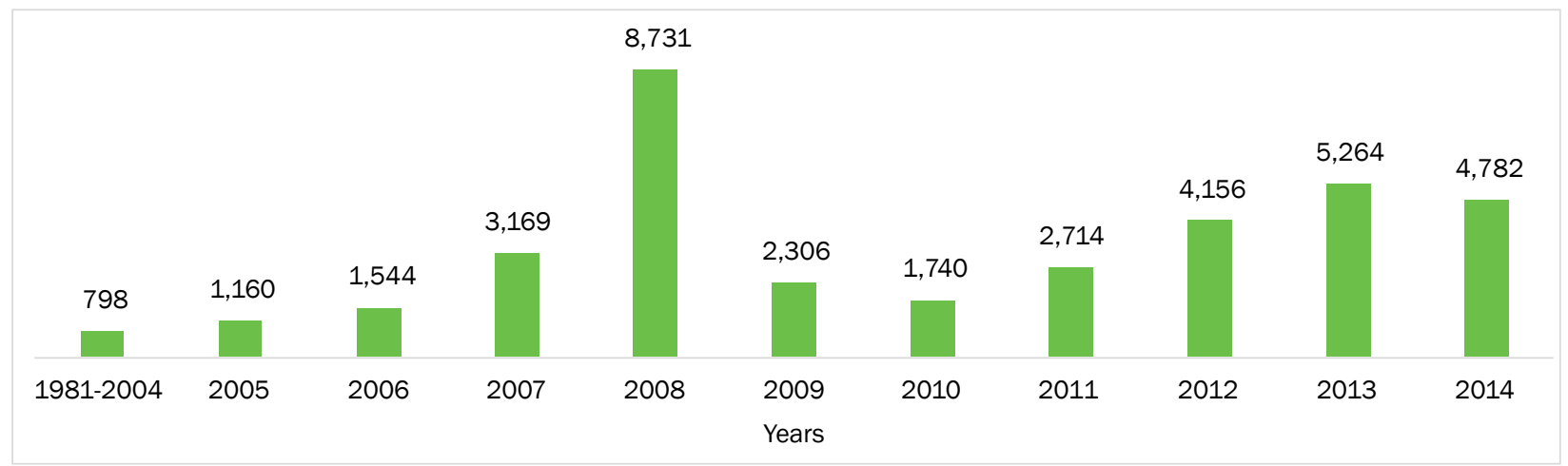

SOURCE: Bureau of Emigration and Overseas Employment, Pakistan.

FIGURE 8: Percent of Households Receiving Any Remittances from within Pakistan, in Punjab Province and the Three Tehsils of Mianwali District, 2008 and 2011

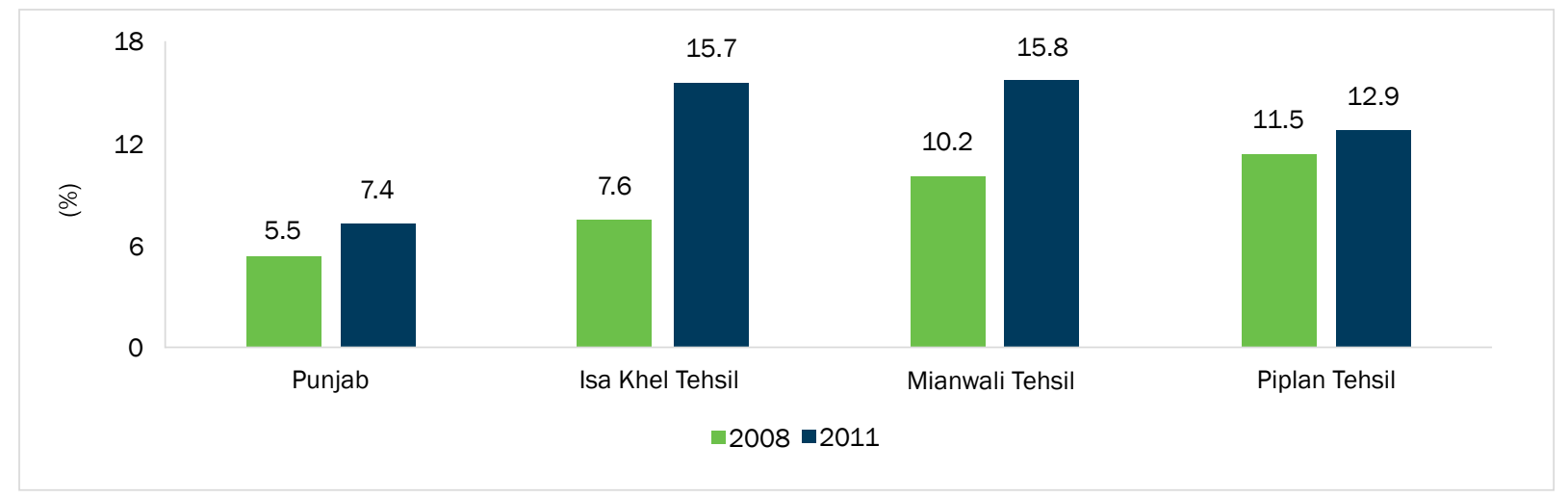

SOURCE: Punjab MICS 2008 and 2011.

Increase in remittances: While there is evidence of migration out of Mianwali

District in the 1970s, mainly to Karachi, it does not subsequently appear to be a major sending district. One indication is in the levels of international migration seen in Figure 7, where the average number of emigrants migrating internationally is minimal (with the exception of 2008) and only picks up after 2012.

The social networks of Mianwali residents do not seem to extend far beyond the district or the country, as we do not see huge international migration shifts. However, comparison of remittances being sent to households in the various tehsils in 2008 and 2011 do show a major jump for Isa Khel (Figure 8), suggesting that the floods may have forced significant migration in quest of livelihood opportunities beyond the tehsil. 
Although there may have been deceleration in population growth rates and increasing rural to urban migration within the district of Mianwali, the evidence that demonstrates greatest demographic change in the worst-hit Isa Khel tehsil is the decline in fertility, which is a recent phenomenon. Greater reliance on remittances is also reflective of migration and associated with the 2010 floods.

These changes suggest that migration is a part of the adaptive response of some households to floods. Given high levels of rural to urban migration, it is especially interesting to note the diversification of livelihoods, and relocation of households to settlements after the floods to locations farther away from possible flood-risk areas. There is a possibility that movement is taking place to newly formed and possibly better-built settlements-as would be expected in the vicinity of Mianwali city for example. This gives rise to the question of whether we may infer that migration demonstrates and contributes to the resilience of some households. However, it is also likely that migration entails new risks, both for those who leave their communities and for the family members they leave behind, which would require further study at the individual, community, and household level for a better understanding of implications for resilience.

\section{CHANGES IN THE ECONOMIC BEHAVIOR OF MIANWALI'S POPULATION THAT MAY BE ASSOCIATED WITH THE 2010 FLOODS, AND IMPLICATIONS FOR FUTURE RESILIENCE}

The agriculture sector is affected by long-term reductions in rainfall, increase in the frequency of droughts and floods, and variability in seasons, particularly higher temperatures and delayed start of colder months. These changes adversely affect crop sowing, maturing, and harvesting cycles. Thus, we fully expect that climate change over a progressive period must have shifted the distribution of opportunities within Mianwali's economy, which is traditionally dominated by agriculture. It is likely that farming practices were affected by the 2010 floods, due both to environmental changes, such as shifts in the riverbed, as well as to adaptation efforts, such as planting of more flood-resistant crops or intensification of agricultural activities (Food Security Cluster 2013). Given the drop in incomes, there may have been distress sales of agricultural assets in the short term.

Moreover, the indications of migration discussed above suggest that income sources of Mianwali's population may have diversified in the aftermath of the 2010 floods. Since it is often men who migrate to other cities for work, female workforce participation may have risen as women were compelled to manage the remaining agricultural work. 
TABLE 4: Ownership of Agricultural Land and Livestock Among Households in Punjab Province, and in Mianwali District and its Tehsils, 2008 and 2011

\begin{tabular}{|l|c|c|c|c|}
\hline & \multicolumn{2}{|c|}{ \% HH owned agricultural land } & \multicolumn{2}{c|}{ \% HH owned livestock } \\
\hline \multicolumn{1}{|c|}{ Region } & 2008 & 2011 & 2008 & 2011 \\
\hline Punjab Province & 34.2 & $33.6^{* *}$ & 50.9 & $48.0^{* *}$ \\
\hline Mianwali District & 39.4 & $31.2^{* *}$ & 68.7 & $60.8^{* *}$ \\
\hline Isa Khel Tehsil & 41.0 & $33.0^{*}$ & 72.4 & $65.0^{*}$ \\
\hline Mianwali Tehsil & 39.0 & $31.1^{* *}$ & 71.5 & $59.9^{* *}$ \\
\hline Piplan Tehsil & 38.7 & $30.0^{* *}$ & 60.3 & 59.0 \\
\hline
\end{tabular}

Differences in ownership of agricultural land and livestock between 2008 and 2011 are significant at $p<0.05$ and are labeled *, and significant at $p<0.01$ and are labeled ${ }^{* *}$.

Differences in ownership of agricultural land in Punjab Province and Mianwali District in 2011 are significant at $p<0.10$ and in ownership of livestock at $p<0.01$

SOURCE: Punjab MICS 2008 and 2011

Decreasing ownership of agricultural land and livestock: We find evidence that the population may have shifted away from agriculture, at least in the years immediately following the 2010 floods. The strongest indication of this change is the decline in household ownership of agricultural land. Table 4 shows that while the shift away from agriculture might well have been happening over time, there was a distinct change in ownership of land between 2008 and 2011 that could be associated with the floods. While the entire Mianwali district experienced a decline in land ownership from 39 to 31 percent, the greater proportion of agricultural ownership in Isa Khel, at 41 percent, declined to the lowest level of 33 percent in 2011 and similarly from 39 to 30 percent in Piplan. Declines in ownership of livestock were also seen across the board. It appears that the sharper changes observed in Mianwali are more likely to be a result of lost land and livestock during the flood than just a shift away from agriculture occurring across the province.

Changes in farming patterns and practices: Potentially, the decrease in the tehsils' ownership of land and livestock between 2008 and 2011 is related to the 2010 flood. Eskander et al. (2018) explore the extent to which rural households in Pakistan adjust their income strategies and savings behavior in response to floods and find that although Pakistani farmers move away from agriculture as an immediate response to disasters, they return within a year. The observed changes in agricultural strategies are not permanent and in fact they are accompanied by increased investments in livestock and seed, and decreased cash savings. In fact, Pakistani farmers allocate a higher proportion of their incomes on replenishing livestock and seeds, showing a determination to revive their post-disaster agricultural activities. Land-utilization patterns have been extracted from Punjab Development Statistics. Data show that cultivable land in Mianwali remained relatively stable at 350,000-375,000 hectares $(865,000-927,000$ acres) from 
$2007-13$, but rose sharply to 428,000 hectares $(1,060,000$ acres) by 2014 . Wheat crop production also rose to 446,000 metric tons (492,000 tons) in 2014 , a maximum for the period 2009-2014. ${ }^{2}$

Changes in male and female employment patterns: A distinct short-term adaptive strategy in Mianwali District is a move away from agricultural to nonagricultural occupations by males. There is also medium-term evidence to show a decline in agricultural jobs, although the sector remains the main source of employment for the district. In Figure 9, we present the percentage of the working age population derived for males and females from Pakistan Standard of Living Measurement Survey data, providing a breakdown of employment into some major occupational categories. The findings show a slight dip in men's participation in work in the year immediately after the flood (2011), and more men report working in elementary ${ }^{3}$ and agricultural occupations than in 2009, just before the floods. But the pre-flood level of male work participation is restored by 2015, with a marginally larger share working in nonagricultural jobs.

Interestingly, there is a rise in the proportion of working females in the post-flood year, going up from 9-21 percent between 2009 and 2011. The rise in working females is concentrated in agriculture and elementary occupational categories. These changes in Mianwali District show that women are likely to be "pushed" into seeking and doing new types of work as an immediate short-term reaction to the floods. The change highlights the interdependency of male and female employment especially in agriculture-most likely women filling in for work that men previously did, before they were forced to look for alternatives. The trend likely reflects the most vulnerable women-those whose husbands and fathers had to look for other work, even temporarily-moving into agriculture and elementary occupations that they normally would not have considered. However, the trend continues to some extent even in 2015, as a larger proportion are still working in agriculture than in 2009, although less than 2011. Data also show that, despite very low levels of work participation, females are beginning to move into the higher-end occupations as well, such as technicians and craft, trade, and sales workers.

Changes in land use: The move away from agriculture may be a long-term change that is not necessarily restricted to Mianwali District but is underway across Punjab Province more generally. However, when we used Landsat satellite imagery to visualize changes in land use in the flood-affected area in Mianwali over the period 2009-17, it showed that after the flood the riverbed expanded, with 12.1 percent water coverage in 2008 increasing to 22 percent in 2011 (Figure 10). The maps in Figure 10 show distinct changes in land use after what seems to be a notable rise in additional land covered by water, which is consistent with the broadening of the riverbed discussed earlier. The area used by settlements hardly changed, reflecting

2Punjab Development Statistics: 2007, 2008, 2009, 2010, 2011, 2012, 2013, 2014. Bureau of Statistics, Punjab, Lahore.

${ }^{3}$ As per Pakistan Standard Classification of Occupations, elementary occupations are: street vendors and related workers, shoe cleaning and other street services, domestic and related helpers, cleaners and launderers, building caretakers, window and related cleaners, messengers, porters, doorkeepers and related workers, garbage collectors and related laborers, agricultural, fishery and related laborers, laborers in mining, construction, manufacturing, and transport and freight handlers. 
FIGURE 9: Percentage of Mianwali's Population in Agricultural and Other Occupations, by Sex, 2009-2015

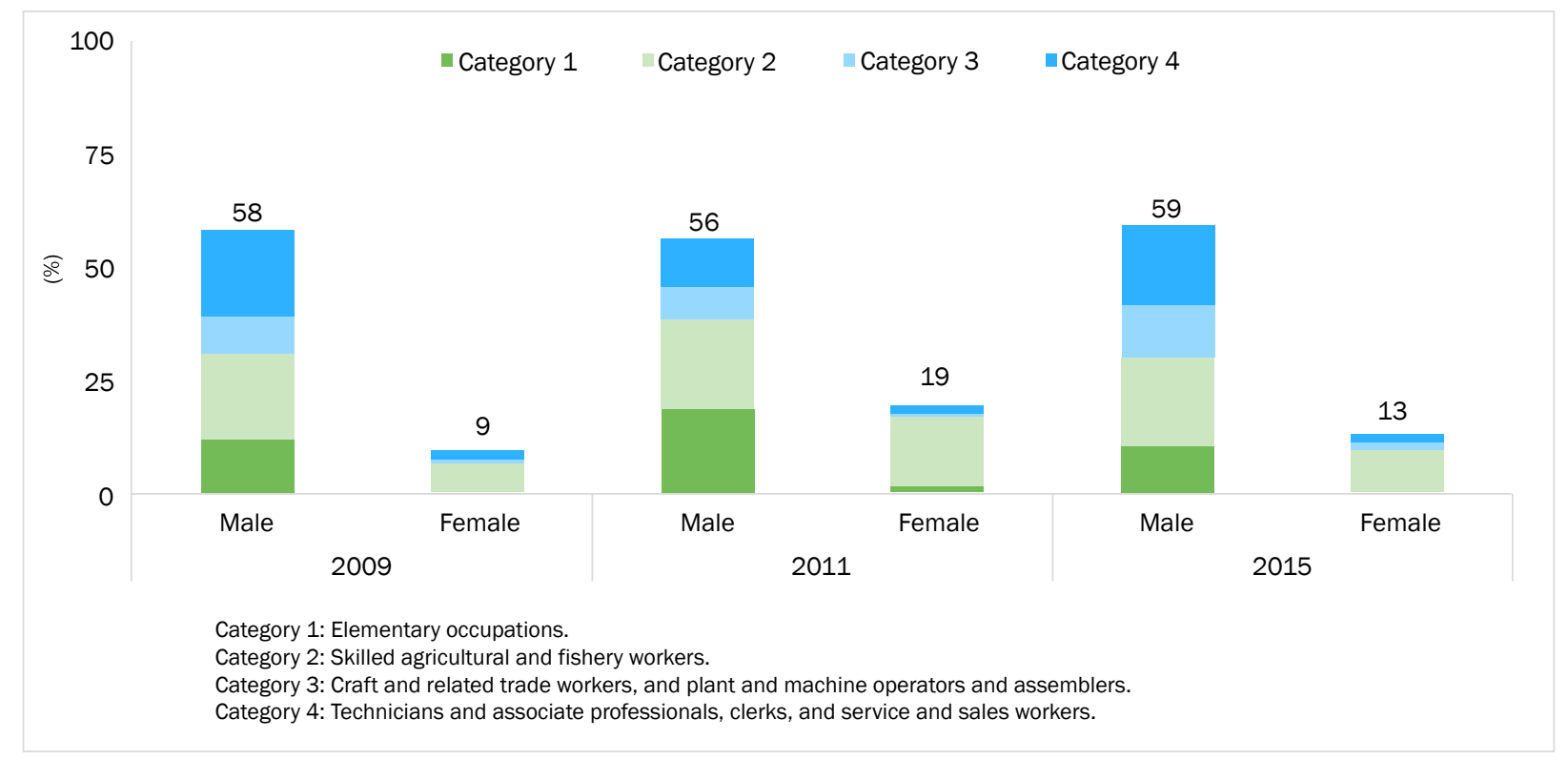

NOTE: The changes in all occupation categories for males are statistically significant at the $p<0.01$ level with the exception of Category 2 (skilled agricultural and fishery workers). In contrast, for females, the changes in all occupational categories are statistically significant at the $p<0.01$ level.

SOURCE: Pakistan Bureau of Statistics (PBS), PSLMS 2008-09, 2010-11 and 2014-15.

that residents are not building long-term housing in these areas but are inclined to utilize the land for agriculture, as the soil may have become relatively richer after the floods.

The implication for future trends is a move away from building back or returning to the flood-prone areas for the purposes of residence, which could result from fear of loss of lives and housing. However, there is no long-term strategy of moving away from or giving up the opportunities offered through agricultural land that may actually be able to provide greater yields in nonflood periods.

\section{POVERTY LEVELS AND LIVING CONDITIONS IN MIANWALI AFTER THE 2010 FLOODS}

Floods, like other natural disasters, often affect human communities broadly, and residents are not equally at risk of loss and harm nor equally able to recover. Poor households are known to be especially vulnerable (Enarson 2002). The 2010 flood had a devastating impact on the affected households and caused a loss to the country's economy of $\$ 16$ billion. To answer one of the questions posed above in "Rationale for the Study" ("Have poverty levels and living conditions improved or deteriorated in Mianwali since the 2010 floods?"), we look at trends in poverty levels in Mianwali and Punjab, as well as in living conditions, and attempt to identify how poorer households, in particular, were able to compensate for their losses and ensure against future shocks. 


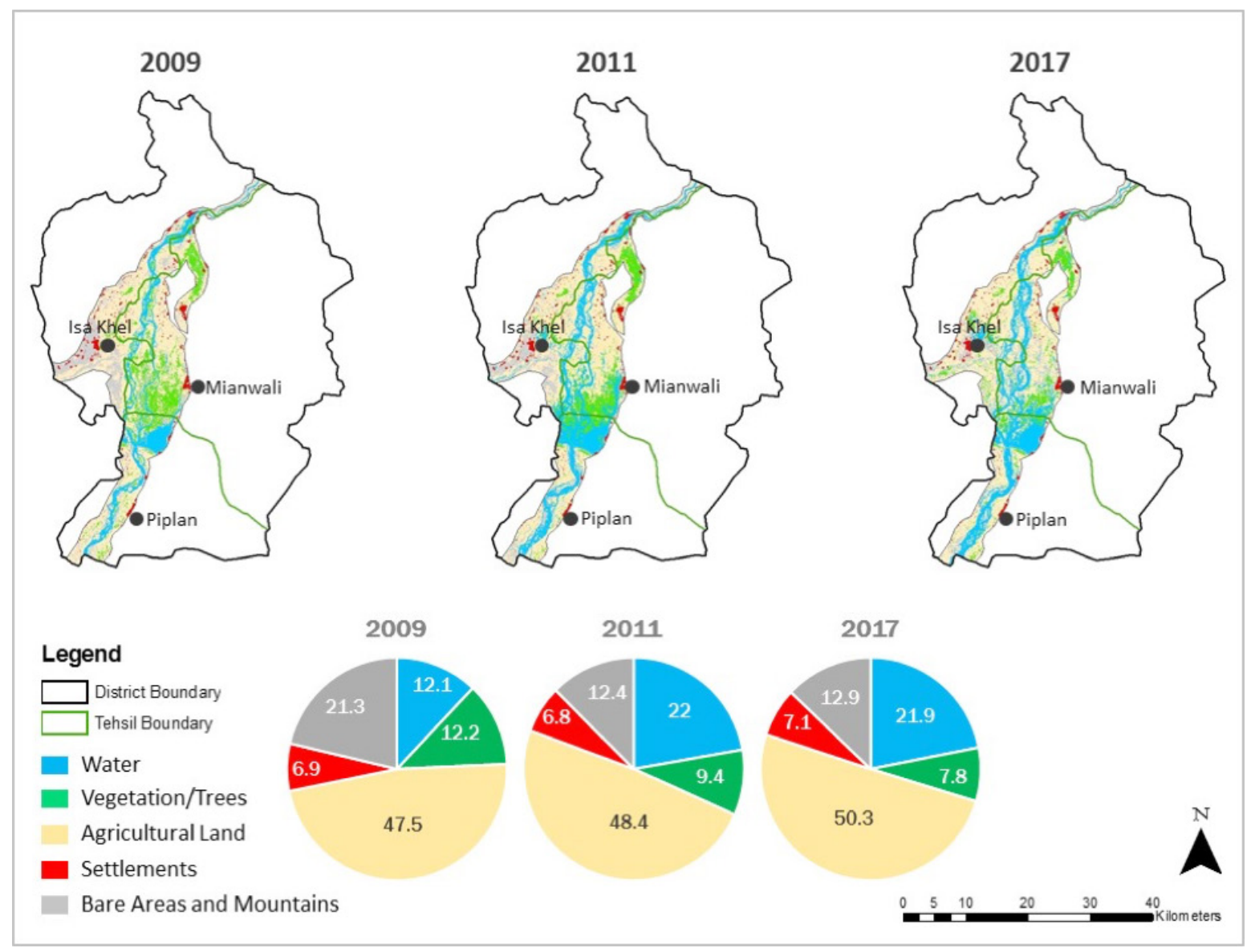

SOURCE: LandScan Population Dataset 2008, 2011, 2016 and Landsat.

Loss of income: According to the results of a national-level survey, the greatest impact of the 2010 floods has been on household income. Even three months after the floods, 66 percent of households did not have enough money to buy essentials such as food, medicine, and fuel. The poverty impact was much higher in rural households (70 percent), compared to urban (33 percent). According to a national study assessing the impact of the floods, regardless of location, 88 percent of households reported reduced income since the floods (WHO and Ministry of Health 2011). The primary cause (63 percent) of lost income was loss of crops or animals. The reported mean monthly household income prior to the floods was 10,900 rupees (US $\$ 131)^{4}$ with 23 percent of the population living on less than 5,000 rupees (US\$60). After the floods, income fell to 2,600 rupees ( $\$ 31$ ), with 75 percent of the population living on less than 5,000 rupees (US\$60) per month. This represents a 75 percent reduction in income across all households (ibid).

In the same study, when asked what their most important current need was at the time of the survey, permanent shelter was identified by 54 percent of respondents, economic support by 52 percent (with 29 percent seeking loans to restart farms or businesses and 23 percent seeking employment), and then food by 31 percent.

${ }^{4}$ US $\$ 1.00=83.20$ Rupees as of 2010. 
FIGURE 11: Economic Status by Income Quintiles in Mianwali Tehsils in Comparison with Punjab ${ }^{5}$ Province in 2008 and 2011, by Tehsil

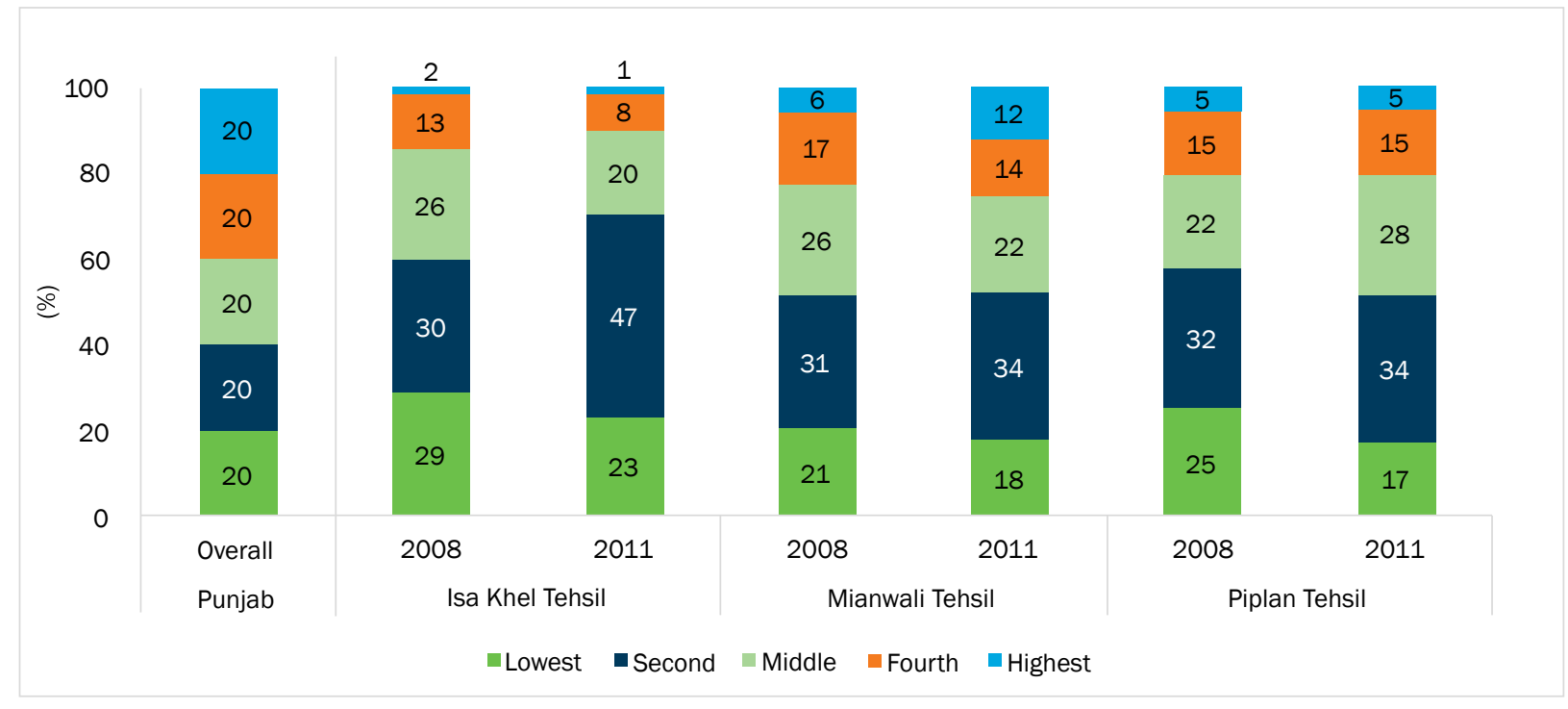

SOURCE: Punjab MICS 2008 and 2011.

The spheres in which more than half the population continued to feel that they were worse off since the floods were: economically/income (88 percent); food quality (75 percent); food availability (71 percent); and shelter (51 percent). According to the survey, 18 percent of the population migrated away from their homes during the floods (WHO and Ministry of Health 2011).

We utilized available sources of household data for the tehsils of Mianwali to assess poverty levels and aspects of quality of living that are most vulnerable to the floods. Our analysis uses Punjab as the standard, which classifies 40 percent of the provincial population as falling into the bottom two quintiles (Figure 11). In comparison, Isa Khel tehsil was much poorer, with 59 percent of its population falling in the lower quintiles. In 2010, the tehsil fell further into poverty with 70 percent of its population falling into the category of Punjab's lowest 40 percent income levels. In contrast, Mianwali and Piplan tehsils did not take a similar hit. In fact, in 2011, there was a slight decline in the proportion of their respective populations living in the equivalent of Punjab's lowest income level.

Increased reliance on social protection and donations: As additional evidence that the population of Isa Khel was the worst affected financially, the MICS data show both a rise in cash donations in the tehsil in 2011 and a dramatic rise in households benefiting from social protection schemes (Table 5). Data from the National Disaster Management Authority (NDMA) and UN Office for the Coordination of Humanitarian Affairs ( $\mathrm{OCHA}$ ) show that several partners did come forward for relief work in Mianwali and child protection efforts seemed to dominate in the area (OCHA 2011). Similar changes were not recorded for Mianwali and Piplan

${ }^{5}$ Punjab Province is the reference category, and the percentage distribution of population in each quintile in 2008 and 2011 is the same (i.e., $20 \%$ ). 
TABLE 5: Proportions of Households Benefiting from Social Protection Schemes and Cash Donations in Punjab Province, and Mianwali District and its Tehsils, 2008 and 2011

\begin{tabular}{|l|c|c|c|c|}
\hline & \multicolumn{2}{|c|}{$\begin{array}{c}\text { Benefiting from cash } \\
\text { donations }\end{array}$} & \multicolumn{2}{c|}{$\begin{array}{c}\text { Benefiting from government social } \\
\text { protection schemes }\end{array}$} \\
\hline \multicolumn{1}{|c|}{ Region } & 2008 & 2011 & 2008 & 2011 \\
\hline Punjab Province & 1.4 & 1.5 & 15.6 & 6.5 \\
\hline Mianwali District & 3.0 & 1.5 & 28.1 & 22.3 \\
\hline Isa Khel Tehsil & 1.0 & 2.7 & 23.6 & 33.0 \\
\hline Mianwali Tehsil & 4.3 & 0.8 & 28.8 & 23.5 \\
\hline Piplan Tehsil & 2.2 & 1.7 & 30.9 & 11.1 \\
\hline
\end{tabular}

SOURCE: Punjab MICS 2008 and 2011.

TABLE 6: Household Amenities and Infrastructure in Punjab Province, and Mianwali District and its Tehsils, 2008 and 2011

\begin{tabular}{|l|c|c|c|c|c|c|c|c|}
\hline & \multicolumn{2}{|c|}{$\begin{array}{c}\text { \% HH population } \\
\text { with water piped into } \\
\text { dwelling }\end{array}$} & \multicolumn{2}{|c|}{$\begin{array}{c}\text { \% HH with Kutcha } \\
\text { floor }\end{array}$} & \multicolumn{2}{c|}{$\begin{array}{c}\% \text { HH with Kutcha } \\
\text { roofing }\end{array}$} & \multicolumn{2}{c|}{$\begin{array}{c}\text { HH with Kutcha } \\
\text { walls }\end{array}$} \\
\hline Region & 2008 & 2011 & 2008 & 2011 & 2008 & 2011 & 2008 & 2011 \\
\hline $\begin{array}{l}\text { Punjab } \\
\text { Province }\end{array}$ & 16.5 & $12.4^{* *}$ & 40.6 & $41.8^{* *}$ & 15.8 & $21.7^{* *}$ & 22.0 & $7.1^{* *}$ \\
\hline $\begin{array}{l}\text { Mianwali } \\
\text { District }\end{array}$ & 17.8 & 18.1 & 57.4 & $61.2^{*}$ & 27.7 & $21.9^{* *}$ & 23.4 & $10.4^{* *}$ \\
\hline $\begin{array}{l}\text { Isa Khel } \\
\text { Tehsil }\end{array}$ & 23.4 & $34.3^{* *}$ & 61.2 & $68.7^{*}$ & 37.3 & $29.8^{*}$ & 26.5 & $13.5^{* *}$ \\
\hline $\begin{array}{l}\text { Mianwali } \\
\text { Tehsil }\end{array}$ & 21.1 & $18.5^{* *}$ & 56.5 & 56.5 & 25.4 & 20.8 & 22.8 & $8.8^{* *}$ \\
\hline $\begin{array}{l}\text { Piplan } \\
\text { Tehsil }\end{array}$ & 7.2 & $4.6^{* *}$ & 55.7 & $63.9^{*}$ & 23.5 & $17.3^{*}$ & 21.8 & $10.7^{* *}$ \\
\hline
\end{tabular}

Differences in percentages of households with kutcha floor, kutcha roofing for 2008 and 2011 are significant at $p<0.05$ and are labeled* Differences that are significant between 2008 and 2011 at $p<0.01$. are labeled**.

Differences in populations with pipe water in dwellings, households with kutcha floor and with kutcha walls between Punjab Province and Mianwali District in 2011 are significant at $<0.01$

SOURCE: Punjab MICS 2008 and 2011.

tehsils. These figures are indicative of the strong response during and after the floods to prevent further disastrous outcomes from accruing and are reflective of the proactive state, civil society, and donor response to calamities, which was also seen to dominate after the calamitous 2005 earthquake that hit Pakistan.

Changes in housing conditions: Our data permit us to look at the status of housing conditions before and after the floods (Table 6). In gauging housing quality, we focus particularly on kutcha (mud or thatch) roofing, which was higher quality in Mianwali District compared with the rest of Punjab. It is obvious that Isa Khel had greater vulnerability, with 37 percent living under kutcha roofs that would have been more susceptible to being washed away by floods. However, it is reassuring also to see that figure decline to 30 percent in 2011, once again reflecting efforts to 
FIGURE 12: Access to Technology Relevant to Flood Early-Warning Dissemination in Urban and Rural Areas of Mianwali District, 2008 and 2011

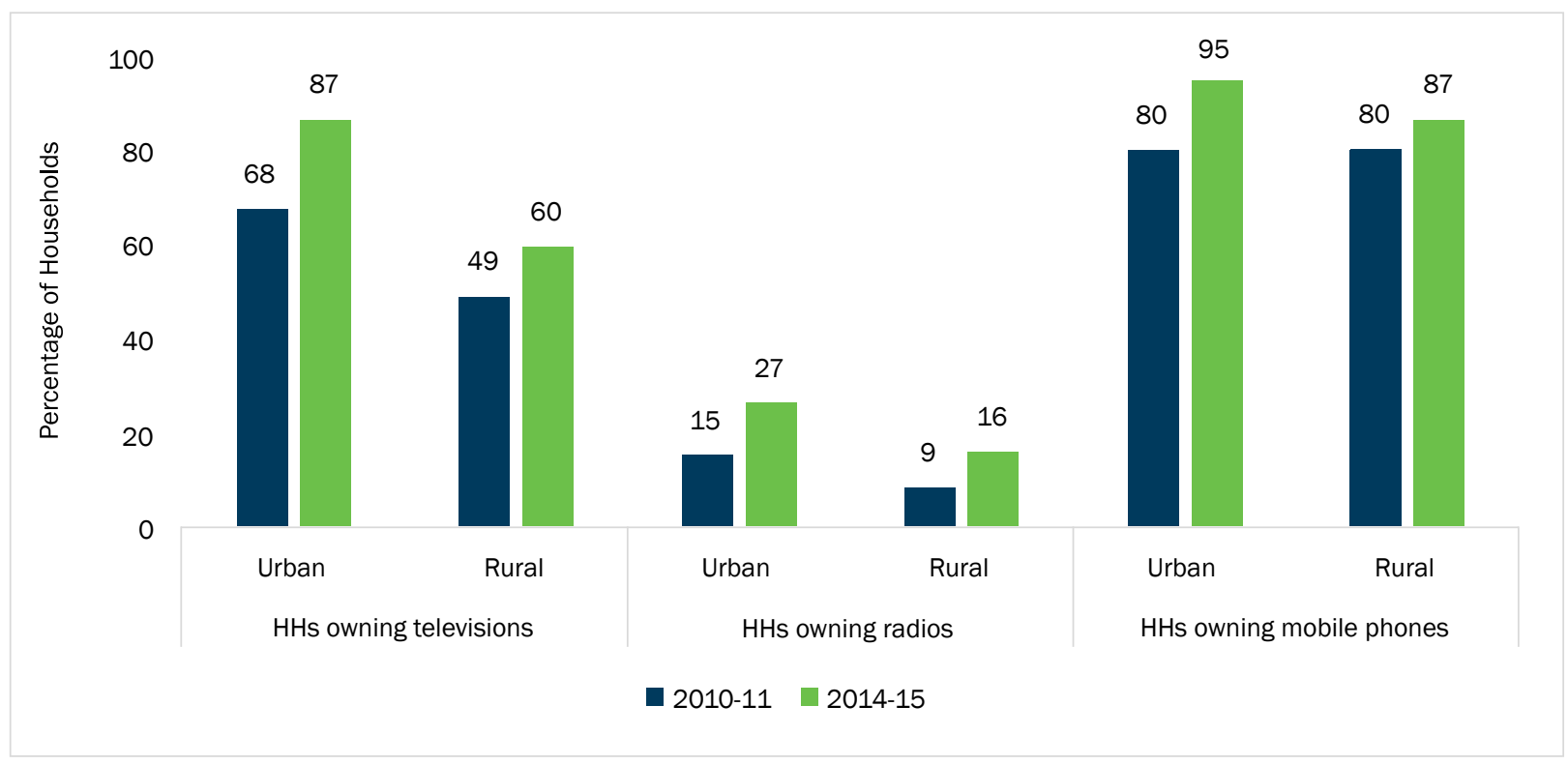

SOURCE: Pakistan Bureau of Statistics (PBS), PSLMS 2010-11 and 2014-15.

build back stronger with additional assistance to the district and to this tehsil. The proportion of households with kutcha walls also declined across all three tehsils in line with trends across Punjab.

In terms of access to water, while the proportion of the population receiving piped water in Mianwali District was comparable in 2008 to the rest of Punjab, Piplan lagged. However, this indicator also improved in 2011 reflecting an improvement in housing quality in Isa Khel tehsil, and in Mianwali more generally. In terms of the quality of flooring, however, Mianwali District depicts a much poorer situation than Punjab.

Changes in ownership of household items: When we look at other household items that are owned by the population of Mianwali District (Figure 12), we see a major rise in the ownership of mobile phones, with very similar levels of ownership in rural and urban areas. There is also a rise in television ownership, but this remains at much lower levels in rural areas of Mianwali. Thus, early-warning signals and sources of information ideal for spreading word about the onset of flooding and rains must be made through mobile technology. Radios, often used for this purpose, penetrate only 16 percent of rural households.

The ranking in Multidimensional Poverty Index for Mianwali District has risen while the rest of Punjab province is experiencing declines in poverty. This implies that districts prone to repeated flooding face a risk of socioeconomic losses that they must overcome each time there is an extreme flood event. We argue that overall Mianwali could have prospered much more had it not experienced the floods 
of 2010. However, we expect this setback to be temporary, due to the increases in external contributions, particularly the stimulation of social safety nets and donations after the flood.

It could be argued that people in Mianwali were living in better housing conditions in 2011 than they were at the time of the 2010 floods. Inter-tehsil differences may persist-because Isa Khel started off with much poorer infrastructure and was more devastated by the floods. Overall, however, there is relatively greater physical protection and more preparedness for future flooding, although anything as drastic as the 2010 rains and floods would most likely have similar outcomes. Change is also seen in terms of greater connectedness to outside ideas through technology, especially mobile phones, in addition to the move toward settlements with better services. The increasing coverage in communication technology can be utilized for better early-warning systems in the future.

\section{CHANGES IN BEHAVIOR WITH RESPECT TO HEALTH (ESPECIALLY REPRODUCTIVE HEALTH) AND EDUCATION AFTER THE 2010 FLOODS}

Previous studies have highlighted changes in reproductive health-seeking behavior as a result of climate-related disasters (Thompson and Sultana 1996; Mutunga and Hardee 2010; McMichael et al. 2012; Pullanikkatil et al. 2013; Rovin et al. 2013; Grace 2017).

Overall the pace of progress against health and reproductive health indicators in Pakistan and in Punjab has been slow, with the potential for shocks (environmental or otherwise) to bring about totally unexpected changes in health and related behaviors. We explored this possibility for Mianwali District from the MICS data. Although a breakdown in health services may have taken place as a result of flooding, making a major part of the health system dysfunctional, relief in the form of health camps and other related services may have led to positive opportunities for improving health. When the women of Mianwali, whose movements outside the home had been restricted up to this time, were compelled to evacuate or find new means for meeting basic household needs, they found new emerging options for interactions, seeking information, and accessing services.

As another important indicator of resilience, we also look at the ability of the affected population to continue their children's schooling. According to Rovin et al. (2013), during times of weather-related difficulties families may withdraw their children from school, either because of financial constraints or to migrate in search of better living conditions or employment. Mansuri (2006) finds that in poor rural Pakistan, where economic migration is usually undertaken by men (leaving femaleheaded households), children in migrant households are more likely to attend school and remain in school compared to those in nonmigrant households, but girls are still significantly more likely to drop out. We use MICS data to assess whether the 2010 floods affected literacy levels and school attendance. 
TABLE 7: Reproductive Health Behavior of Currently Married Women Aged 15-49 across Punjab Province, and Mianwali District and its Tehsils, 2008 and 2011

\begin{tabular}{|l|c|c|c|c|c|c|c|c|c|c|}
\hline & \multicolumn{2}{|c|}{$\begin{array}{c}\text { Use of } \\
\text { contraception } \\
\text { (any method), } \\
\text { \% of women }\end{array}$} & \multicolumn{2}{|c|}{$\begin{array}{c}\text { Antenatal care } \\
\text { (any skilled } \\
\text { personnel), } \\
\text { \% of women }\end{array}$} & \multicolumn{2}{|c|}{$\begin{array}{c}\text { Baby delivered in } \\
\text { health facility, } \\
\text { \% of women }\end{array}$} & \multicolumn{2}{c|}{$\begin{array}{c}\text { Postnatal care } \\
\text { (any skilled } \\
\text { personnel), } \\
\% \text { of women }\end{array}$} & \multicolumn{3}{|c|}{$\begin{array}{c}\text { Currently } \\
\text { pregnant, } \\
\% \text { of women }\end{array}$} \\
\hline Region & 2008 & 2011 & 2008 & 2011 & 2008 & 2011 & 2008 & 2011 & 2008 & 2011 \\
\hline $\begin{array}{l}\text { Punjab } \\
\text { Province }\end{array}$ & 32.2 & $35.2^{* *}$ & 52.7 & $74.2^{* *}$ & 38.3 & $53.5^{* *}$ & 40.9 & $37.9^{* *}$ & 11.2 & $11.9^{* *}$ \\
\hline $\begin{array}{l}\text { Mianwali } \\
\text { District }\end{array}$ & 19.6 & $32.3^{* *}$ & 43.6 & $76.5^{* *}$ & 28.7 & $59.4^{* *}$ & 29.0 & $39.8^{* *}$ & 11.0 & 9.6 \\
\hline $\begin{array}{l}\text { Isa Khel } \\
\text { Tehsil }\end{array}$ & 26.2 & $40.5^{* *}$ & 39.9 & $78.3^{* *}$ & 21.9 & $70.5^{* *}$ & 19.3 & $37.6^{*}$ & 9.4 & 9.2 \\
\hline $\begin{array}{l}\text { Mianwali } \\
\text { Tehsil }\end{array}$ & 19.2 & $31.9^{* *}$ & 46.4 & $78.0^{* *}$ & 29.1 & $61.0^{* *}$ & 32.0 & $47.6^{* *}$ & 11.9 & $7.3^{*}$ \\
\hline $\begin{array}{l}\text { Piplan } \\
\text { Tehsil }\end{array}$ & 14.7 & $26.7^{* *}$ & 42.6 & $74.1^{* *}$ & 34.7 & $50.8^{*}$ & 33.4 & 28.2 & 10.9 & 13.7 \\
\hline
\end{tabular}

Differences in percentages of women who delivered in health facilities, percentage of women who seek postnatal care, and percentage of women currently pregnant between 2008 and 2011 are significant at $p<0.05$ and are labeled*. Differences that are significant between 2008 and 2011 at $p<0.01$ are labeled**.

Differences in percentages of women using contraception, percentage of women currently pregnant in Punjab Province and Mianwali District in 2011 are significant at $p<0.05$, and the differences in percentages of women who delivered in health facilities in Punjab versus Mianwali is significant at $\mathrm{p}<0.1$.

SOURCE: Punjab MICS 2008 and 2011.

More women are seeking antenatal and delivery care: The most striking of our findings relates to more positive health-seeking behaviors across Mianwali District. In general women were more likely to seek antenatal and delivery care after the 2010 floods than before (see Table 7). While a notable increase in skilledbirth attended delivery is also seen across Punjab Province, the rise in all tehsils of Mianwali up to the province levels is dramatic.

Increased contraceptive use: Contraceptive use appears to have risen sharply from 20 to 32 percent in Mianwali District and even more dramatically in its subarea of Isa Khel which was the worst affected of the tehsils, in a brief period of three years (2008-11). In comparison, contraceptive use hardly rose from 32 to 35 percent in Punjab overall. Although there are no readily available figures for relief camps and increased access to services in Mianwali, the relief operations did include mobile clinics and other health services in the area. Undoubtedly, this must be one of the outcomes of the forced exposure of flood-affected families to new sources of reproductive health services, either in their own areas or by moving temporarily to other better-served areas. Notably, there is some evidence of the rebuilding of health facilities and addition of camps and other health service options in the district after the 2010 floods (OCHA 2011).

Fertility is falling: The final supporting evidence of a fertility decline emerges from lower numbers of children under age 5 ; while this decline has occurred across Mianwali District, it is especially pronounced in Isa Khel tehsil. This is truly unexpected given that Isa Khel is the least developed area of the district. 
TABLE 8: Literacy (10 years and older) and Primary Enrollment Rates in Punjab Province, and Mianwali District and its Tehsils, 2008 and 2011

\begin{tabular}{|l|c|c|c|c|c|c|}
\hline & \multicolumn{2}{|c|}{$\begin{array}{c}\text { Literacy rate-10 years and } \\
\text { older }\end{array}$} & \multicolumn{2}{c|}{$\begin{array}{c}\text { Primary school NAR } \\
\text { (5-9years) }\end{array}$} & \multicolumn{2}{c|}{$\begin{array}{c}\text { Gender parity index at } \\
\text { primary school NAR }\end{array}$} \\
\hline Region & 2008 & 2011 & 2008 & 2011 & 2008 & 2011 \\
\hline $\begin{array}{l}\text { Punjab } \\
\text { Province }\end{array}$ & 59.3 & 59.5 & 52.9 & $59.4^{* *}$ & 0.96 & 0.95 \\
\hline $\begin{array}{l}\text { Mianwali } \\
\text { District }\end{array}$ & 56.8 & 57.2 & 52.9 & $61.2^{* *}$ & 0.84 & 0.89 \\
\hline $\begin{array}{l}\text { Isa Khel } \\
\text { Tehsil }\end{array}$ & 48.0 & 48.5 & 43.4 & $54.6^{*}$ & 0.80 & 0.78 \\
\hline $\begin{array}{l}\text { Mianwali } \\
\text { Tehsil }\end{array}$ & 59.9 & 58.2 & 55.9 & $62.3^{*}$ & 0.86 & 0.85 \\
\hline $\begin{array}{l}\text { Piplan } \\
\text { Tehsil }\end{array}$ & 59.0 & 62.5 & 56.3 & $64.1^{*}$ & 0.85 & 1.04 \\
\hline
\end{tabular}

NAR=Net attendance ratio.

Differences in primary net attendance ratio for 2008 and 2011 are significant at $p<0.05$ and are labeled*. Differences that are significant between 2008 and 2011 at $p<0.01$ are labeled**.

SOURCE: Punjab MICS 2008 and 2011.

MICS 2014 reports the total fertility rate (TFR) in Mianwali District as 3.3, but unfortunately, fertility data is not available at the tehsil level.

The observed rapid reproductive change is consistent with similar findings from Ethiopia and from Bangladesh, where studies (Thompson and Sultana 1996; Rovin et al. 2013) show people affected by natural disasters consider smaller families to be an advantage in terms of resilience and adaptation. If we assume that women in Isa Khel had unmet need both for family planning and for institutional deliveries, they readily took up their use once such services were available as part of the relief operations, in this case through the United Nations Population Fund (UNFPA) and WHO.

Primary school attendance continues to rise: Primary school enrollment has generally been rising across Pakistan and continued to do so despite the 2010 floods (see Tables 8 and 9). The gender parity index is almost 1.0. At the tehsil level, we see the greatest improvement between 2008 and 2011 in Isa Khel, although the tehsil still had the lowest enrollment ratio in the district and the widest gender gap.

For primary school attendance, gender gaps persist in two tehsils: Genderdisaggregated data indicate that girls' primary school enrollment is rising in all three tehsils of Mianwali (Tables 8 and 9). However, the pace and status of girls relative to boys in their tehsil, and relative to girls in other tehsils, varies considerably. Between 2008 and 2011, girls' enrollment increased considerably in Isa Khel, but not as rapidly as among boys. In contrast, the gender gap in primary enrollment seems to have closed in Piplan, with girls marginally in the lead. 
TABLE 9: Primary and Middle/Secondary School Net Attendance Ratio-Punjab and Mianwali Tehsils, 2008 and 2011

\begin{tabular}{|c|c|c|c|c|c|c|c|c|c|c|c|c|c|c|c|c|}
\hline & \multicolumn{4}{|c|}{ Punjab Province } & \multicolumn{4}{|c|}{ Isa Khel Tehsil } & \multicolumn{4}{|c|}{ Mianwali Tehsil } & \multicolumn{4}{|c|}{ Piplan Tehsil } \\
\hline & \multicolumn{2}{|c|}{ Boys } & \multicolumn{2}{|c|}{ Girls } & \multicolumn{2}{|c|}{ Boys } & \multicolumn{2}{|c|}{ Girls } & \multicolumn{2}{|c|}{ Boys } & \multicolumn{2}{|c|}{ Girls } & \multicolumn{2}{|c|}{ Boys } & \multicolumn{2}{|c|}{ Girls } \\
\hline & $\begin{array}{l}\infty \\
\stackrel{\sim}{\sim}\end{array}$ & 로 & $\begin{array}{l}\infty \\
\stackrel{\sim}{\sim}\end{array}$ & ్ㅠ & 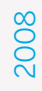 & न्̈ & $\begin{array}{l}\infty \\
\stackrel{\sim}{\sim}\end{array}$ & تี & $\begin{array}{l}\infty \\
\stackrel{\sim}{\circ}\end{array}$ & ت्ञ & $\begin{array}{l}\infty \\
\stackrel{\sim}{\sim}\end{array}$ & $\vec{\sim}$ & $\begin{array}{l}\infty \\
\stackrel{\sim}{\circ}\end{array}$ & न्ञ & 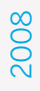 & 표 \\
\hline $\begin{array}{l}\text { Primary } \\
\text { school net } \\
\text { attendance } \\
\text { ratio (\% } \\
\text { of children } \\
\text { aged 5-9) }\end{array}$ & 54 & 61 & 52 & 58 & 48 & 61 & 38 & 48 & 60 & 67 & 52 & 57 & 60 & 63 & 51 & 66 \\
\hline $\begin{array}{l}\text { Middle/ } \\
\text { secondary } \\
\text { school net } \\
\text { attendance } \\
\text { ratio (\% } \\
\text { of children } \\
\text { aged } \\
10-14)\end{array}$ & 30 & 41 & 28 & 39 & 25 & 58 & 11 & 20 & 33 & 55 & 25 & 33 & 31 & 60 & 21 & 41 \\
\hline
\end{tabular}

SOURCE: MICS Punjab 2008 and 2011

Middle/secondary school attendance has increased among boys, but girls lag behind. Between 2008 and 2011, there has been a conspicuous jump in the proportion of boys attending middle/secondary school in Mianwali District. This is most prominent in Isa Khel, where the proportion has more than doubled, exceeding the proportion in more urbanized Mianwali. A doubling of boys' enrollment is also seen in Piplan. The huge extent of change appears to be a strong hint of adaptive behavior after the 2010 floods, perhaps linked with the desire to prepare sons for nonagricultural livelihoods or work in cities. Girls in Piplan, again, are closest to their male peers in this respect, and those in Isa Khel lag the farthest behind. Nevertheless, enrollment levels in 2011 are double those in 2008 in both tehsils (Table 9), which is roughly the same pace of change observed among boys in the tehsils.

Perhaps the most dramatic of our findings is that we do see a change in fertility before and after the 2010 floods. Isa Khel, previously behind in terms of all reproductive health indicators, managed to catch up and surpass more developed neighboring tehsils. If the behavior is profound and real, then Isa Khel residents will most definitely benefit from better health-seeking behavior and lower fertility. However, many of the instigating factors may have been related to flood-relief operations and the change may not sustain over a longer period. Here, it is imperative to do further research to gain insights from women in particular about their experience pre- and post-floods in terms of their reproductive decisionmaking and access. 
CONCLUSIONS

This study of the effects of the $\mathbf{2 0 1 0}$ floods on Mianwali District and its three tehsils highlights the need to include demographic and health information in the analysis of natural disasters.

- The choice of Mianwali District was intuitively appealing as the district straddles the Indus River and it was possible to observe the extent of the effects of the floods within the vicinity and farther away. In ways, the three tehsils offered a design for extracting a comparative perspective where one tehsil, in this case Isa Khel, was almost entirely affected and the other two were partially affected by the floods.

- Interestingly, there are also signs of long-term topographical changes around the course of the Indus through Mianwali, owing to the heavy flow of rain and river waters over time. There are also long-, medium-, and short-term changes observed in the local population, from which we have tried to infer signs of resilience and adaptive behavior to the extent that availability of data and satellite imagery permit.

- However, these suggested associations require additional study to confirm the observed patterns, as other factors may have also played a role.

One of the most obvious forms of reactions to the flooding, in both the long and short term, were displacement patterns.

- During the acute period of floods, several thousand individuals had to leave homes that were under water, but most returned and have largely built back the structures affected or destroyed.

- To some extent the improvement of housing conditions was unexpected because we do record higher levels of poverty as measured by the Multidimensional Poverty Index (Planning Commission of Pakistan, UNDP Pakistan, and OPHI 2016). The return, with stronger houses, potentially reflects resilience.

- Presumably assistance received during flood-relief operations plays a role in this: we are able to capture greater inputs from the outside world in terms of remittances, cash donations, and social safety-net programs being diverted to Isa Khel.

- Ownership of mobile phones is also rising, in both urban and rural areas suggesting that mobile technology can and must be an essential element of flood early-warning systems.

There is evidence of a gradual but definitive shifting within the district from rural to urban settlements, mostly of persons and possibly households from Isa Khel to Mianwali and Piplan tehsils.

- In fact, data drawn from the preliminary results of the 2017 Population and Housing Census suggests that Mianwali may have converted from a primarily rural to a fast-urbanizing district in the last two decades.

- Moving away to more urbanized settlements to the east of the Indus is a long- and medium-term strategy instigated at least partially by the rising vulnerabilities of being in a part of the Indus Valley that is relatively more exposed to flood hazard. 
Another adaptation strategy relates to changing livelihoods.

- There are signs of seeking other forms of employment to avoid full dependence on agriculture at both ends of the economic range-with the more educated able to seek clerical and other white-collar jobs, but the poorer and uneducated entering services, blue-collar, and more menial occupations, such as cleaning.

- In addition, markedly higher female work participation, mainly in low-end jobs, certainly appears to be a part of households' immediate coping strategy; although it declines in subsequent years, it remains higher than pre-flood levels, indicating that women working may be part of the longer-term adaptive strategy as well.

- Ownership of agricultural land declined, but not drastically, and may reverse itself as we see a dip in agricultural yield around the floods but frequently followed by a recovery.

Of great surprise were the observed changes in reproductive health behavior, especially in Isa Khel.

- The rapid uptake of contraceptive use and delivery in institutions suggest that the women were ready for a change in reproductive behavior that likely became possible through the additional availability of health services during flood-relief operations.

- There is also a rise in schooling throughout Mianwali, particularly for girls' enrollments, though Isa Khel lags behind. In contrast, Piplan tehsil is moving toward gender parity and beyond for girls' primary schooling.

The behaviors observed, both as adaptive responses to the 2010 floods and as part of longer-term trends, indicate that the people of Mianwali are more mobile; better connected to sources of information, health services, and social protection; and buillding relatively more flood-resistant housing.

- They are also opting for smaller families, exploring livelihoods that are less dependent on the vagaries of climate, and increasingly choosing to send their children to school at both the primary and secondary level.

- It is too soon to say whether Isa Khel tehsil in particular and Mianwali District more broadly may be in recovery, however it is evident that the floods have contributed to an inflow of modern, more outward-looking behaviors, and a change in values that may not be reversible.

- At least in terms of the elements of resilience explored in this study, it is likely that the population is better prepared to cope and recover in the event of another major flood.

We acknowledge that many of our findings are preliminary and require further investigation and generation of new primary data.

- We need to collect household and community data to corroborate and elucidate some of our findings by learning about men's and women's views on their own resilience and adaptation patterns.

- Furthermore, we may utilize a similar approach to look at other districts affected severely by the floods in Punjab and in Sindh provinces.

- Above all, we see this as the beginning of a research agenda that can capitalize on data from the Population Census, the Agriculture Census, and other sources to build a national overview of how climate change is affecting people, livelihoods, and health, and vice versa, in Pakistan. 
REFERENCES

Arai, T. 2012. "Rebuilding Pakistan in the aftermath of the floods: Disaster relief as conflict prevention," Journal of Peace-building and Development 7(1): 51-65.

Arif, G.M. 2005. "Internal Migration and Household Well-being: Myth or Reality," in Hisaya Oda (ed.) Internal Labour Migration in Pakistan. Institute of Developing Economies, Japan External Trade Organization, Chiba, Japan.

Arif, G.M and S. Ibrahim. 1998. "The process of urbanization in Pakistan, 1951-81," The Pakistan Development Review 37(4): 507-522.

Asian Development Bank and World Bank. 2010. Pakistan Floods 2010 Preliminary Damage and Needs Assessment. Report number 58290. Islamabad: Pakistan

Bartlett, S. 2008. "Climate change and urban children: Impacts and implications for adaptation in low- and middle-income countries," Environment and Urbanization 20(2): 501-519.

Brooks, N. 2003. Vulnerability, Risk and Adaptation: A Conceptual Framework. Tyndall Centre for Climate Change Research. Working Paper No. 38. Norwich, United Kingdom: Tyndall Centre for Climate Change Research.

Bryan, G., S. Chowdhury, and A.M. Mobarak, 2014. "Underinvestment in a profitable technology: The case of seasonal migration in Bangladesh," Econometrica 82(5): 1671-1748.

Cain, M. 1981. "Risk and insurance: Perspectives on fertility and agrarian change in India and Bangladesh," Population and Development Review 7(3): 435-474.

Cattaneo, C. and G. Peri. 2016. “The migration response to increasing temperatures,"Journal of Development Economics 122: 127-146

Dodman, D., J. Ayers, and S. Huq. 2009. “Building Resilience,” in State of the World 2009: Into a Warming World. The World Watch Institute. New York: W.W. Norton and Company, pp. 151-168.

Enarson, E. 2002. "Gender issues in natural disasters: Talking points and research needs." ILO InFocus Programme on Crisis Response and Reconstruction Workshop. Geneva, May 3-5, 2000.

Eskander, S.M.S.U., S. Fankhauser, S. Jha, S. Batool, and A. Qaisrani. 2018. "Do natural disasters change savings and employment choices? Evidence from Pakistan." Grantham Research Institute on Climate Change and the Environment (Working Paper No. 293) and Centre for Climate Change Economics and Policy (Working Paper No. 328), London, UK: London School of Economics.

Federal Flood Commission. 2015. "Annual Flood Report 2015." Office of the Chief Engineering Advisor and Chairman, Federal Flood Commission, Ministry of Water and Power, Government of Pakistan: Islamabad.

Food Security Cluster Pakistan. 2013. “Livelihood recovery appraisal 2013 of households affected by flooding in 2012 in Punjab, Sindh and Balochistan.

Government of Punjab. 2009. “Punjab Development Statistics 2010.” Bureau of Statistics, Government of Punjab, Lahore, Pakistan.

- - - 2010. Flood Inquiry Report Part II-Lahore High Court. Report of the Judicial Flood Inquiry Tribunal, 2010. Government of Punjab, Lahore, Pakistan

Grace, K. 2017. "Considering climate in studies of fertility and reproductive health in poor countries," Nature Climate Change 7: 479-485.

Guardian. 2010. "Pakistan floods are a 'slow-motion tsunami'-Ban Ki-moon.” https://www.theguardian.com/ world/2010/aug/19/pakistan-flood-ban-ki-moon

Homer-Dixon, T.F. 1999. Environment, scarcity, and violence. Princeton: Princeton University Press.

Kreft, S., D. Eckstein, and I. Melchior. 2016. “Global Climate Risk Index 2017.” Germanwatch.

Lee, S.W. 2001. Environmental matters: Conflict refugees and international relations. World Human Development Institute Press, Seoul and Tokyo.

Looney, R. 2012. “Economic impacts of the floods in Pakistan," Contemporary South Asia 20(2): 225-241

Mansuri, G. 2006. "Migration, school attainment, and child labor: Evidence from rural Pakistan." World BankDevelopment Research Group (DECRG). World Bank Policy Research Working Paper No. 3945.

McMichael, C., J. Barnett, and A.J. McMichael. 2012. "An ill wind? Climate change, migration, and health," Environmental Health Perspectives 120(5): 646-654.

MICS. 2009. Multiple Indicator Cluster Survey, Punjab 2007-08, Final Report, Pakistan. Bureau of Statistics Punjab, Planning \& Development Department, Government of the Punjab and UNICEF Punjab.

-_- . 2012. Multiple Indicator Cluster Survey, Punjab 2011, Final Report, Pakistan. Bureau of Statistics Punjab, Planning \& Development Department, Government of the Punjab and UNICEF Punjab.

- - - 2016. Multiple Indicator Cluster Survey, Punjab 2014, Final Report, Pakistan. Bureau of Statistics Punjab, Planning \& Development Department, Government of the Punjab and UNICEF Punjab.

Ministry of Climate Change. 2012. National Climate Change Policy. Islamabad: Ministry of Climate Change, Government of Pakistan. 
Mueller, V., C. Gray, and K. Kosec. 2014. “Heat stress increases long-term human migration in rural Pakistan," Nature Climate Change 4(3): 182-185

Mutunga, C. and K. Hardee. 2010. "Population and reproductive health in National Adaptation Programmes of Action (NAPAs) for climate change in Africa," African Journal of Reproductive Health 14(4): 133-145.

Najam-u-Din. 2010. Internal Displacement in Pakistan: Contemporary Challenges. Human Rights Commission of Pakistan.

NDMA. 2011. “Annual Report 2010.” National Disaster Management Authority (NDMA): Islamabad.

Nelson, G.C., M.W. Rosegrant, J. Koo, R. Robertson, T. Sulser, T. Zhu, and M. Magalhaes. 2009. Climate change: Impact on Agriculture and Costs of Adaptation (Vol. 21). International Food Policy Research Institute.

OCHA. 2011. “Pakistan Floods 2010-Mianwali District Profile." Glide No FI-2010-000141-Pak.

Orr, A.W., A.S.M.N. Islam, M.R. Islam, M. Shah-E-Alam, and M.A. Jabbar. 1992. “Vulnerable farmers in deep water rice environment: The Impact of the 1988 floods," in Reducing Small Farmer in Bangladesh: Proceedings of the BRRI Workshop. Dhaka, Bangladesh, May 30-31, 1992, pp. 33-50.

Pakistan Bureau of Statistics (PBS). 2009. Pakistan Social and Living Standards Measurement Survey (PSLMS), 2008-09. Islamabad: Government of Pakistan, Statistics Division, Pakistan Bureau of Statistics.

- - . 2011. Pakistan Social and Living Standards Measurement Survey (PSLMS), 2010-11. Islamabad: Government of Pakistan, Statistics Division, Pakistan Bureau of Statistics.

- - - 2015. Pakistan Social and Living Standards Measurement Survey (PSLMS), 2014-15. Islamabad: Government of Pakistan, Statistics Division, Pakistan Bureau of Statistics.

- 2017. 6th Population and Housing Census, 2017. Islamabad: Government of Pakistan, Statistics Division, Pakistan Bureau of Statistics

Patt, A.G., A. Dazé, and P. Suarez. 2009. “Gender and climate change vulnerability: What's the problem, what's the solution?" in M. Ruth and M.E. Ibarraran (eds.) Distributional Impacts of Climate Change and Disasters: Concepts and Cases. Cheltenham, UK: Edward Elgar Publishing,

pp. 82-102.

Planning Commission of Pakistan, United Nations Development Programme Pakistan, and Oxford Poverty and Human Development Initiative. 2016. Multidimensional Poverty in Pakistan. Islamabad, Pakistan: Ministry of Planning, Development, and Reform.

Pullanikkatil, D., B. Kaneka, W. Phalira, C. Mkanthama, and S. Chiotha. 2013. "Linkages between population, reproductive health, gender and climate change adaptation in Malawi." Population Action International and LEAD Southern and Eastern Africa, Zomba, Malaw.

Rovin, K., K. Hardee, and A. Kidanu. 2013. “Linking population, fertility, and family planning with adaptation to climate change: Perspectives from Ethiopia," African Journal of Reproductive Health 17(3): 15-29.

Salik, K.M., A. Qaisrani, M.A. Umar, and S.M. Ali. 2017. Migration Futures in Asia and Africa: Economic Opportunities and Distributional Effects - the Case of Pakistan, Pathways to Resilience in Semi-arid Economies. Islamabad, Pakistan: Sustainable Development Policy Institute.

Solberg, K. 2010. “Worst floods in living memory leave Pakistan in paralysis," The Lancet 376 (9746): 1039-1040.

Strömberg, D. 2007. “Natural disasters, economic development, and humanitarian aid," Journal of Economic Perspectives 21(3): 199-222.

SUPARCO. 2010. “Pakistan Floods/Rains 2010: Rapid Crop Damage Assessment.” Series No. 1. SUPARCO.

Swain, A. 1996. "Environmental migration and conflict dynamics: Focus on developing regions," Third World Quarterly 17(5): 959-974.

Thompson, P.M. and P. Sultana. 1996. "Distributional and social impacts of flood control in Bangladesh," Geographical Journal 16(1): 1-13.

United Nations. 2005. “Table 6 - Demographic Yearbook 2005.” https://unstats.un.org/unsd/demographic/ products/dyb/dyb2005/notestab06.pdf

UNDP. 2016. “Before the flood." United Nations Development Programme, Pakistan. http://www.pk.undp.org/ content/pakistan/en/home/presscenter/articles/2016/11/04/before-the-flood-.html

Warner, K. 2011. "Environmental change and migration: Methodological considerations from ground-breaking global survey," Population and Environment 33(1): 3-27.

WHO and Ministry of Health. 2011. Pakistan Floods 2010: Impact Assessment. http://floods2010.pakresponse. info/LinkClick.aspx?fileticket=JoeGLfkJvcg\%3D\&tabid=86\&mid=548

World Bank. 2018. The Climate Change Knowledge Portal (CCKP). Historical Climate Data (Updated to 2015). 


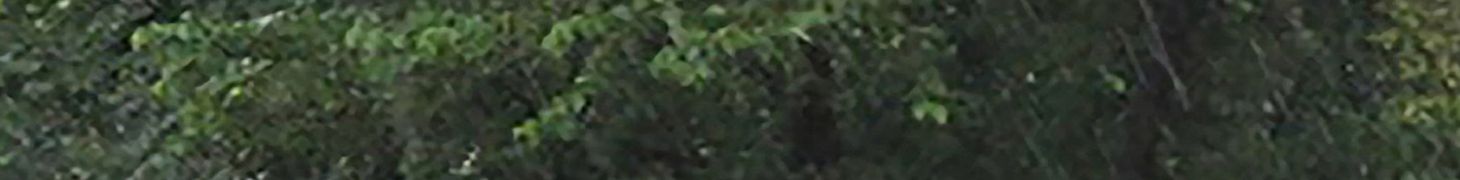

sis

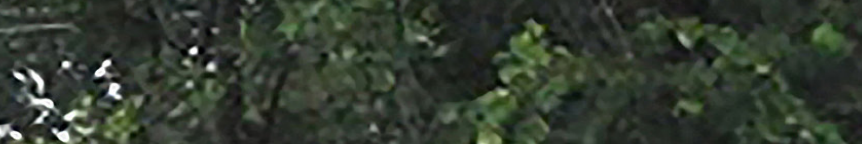

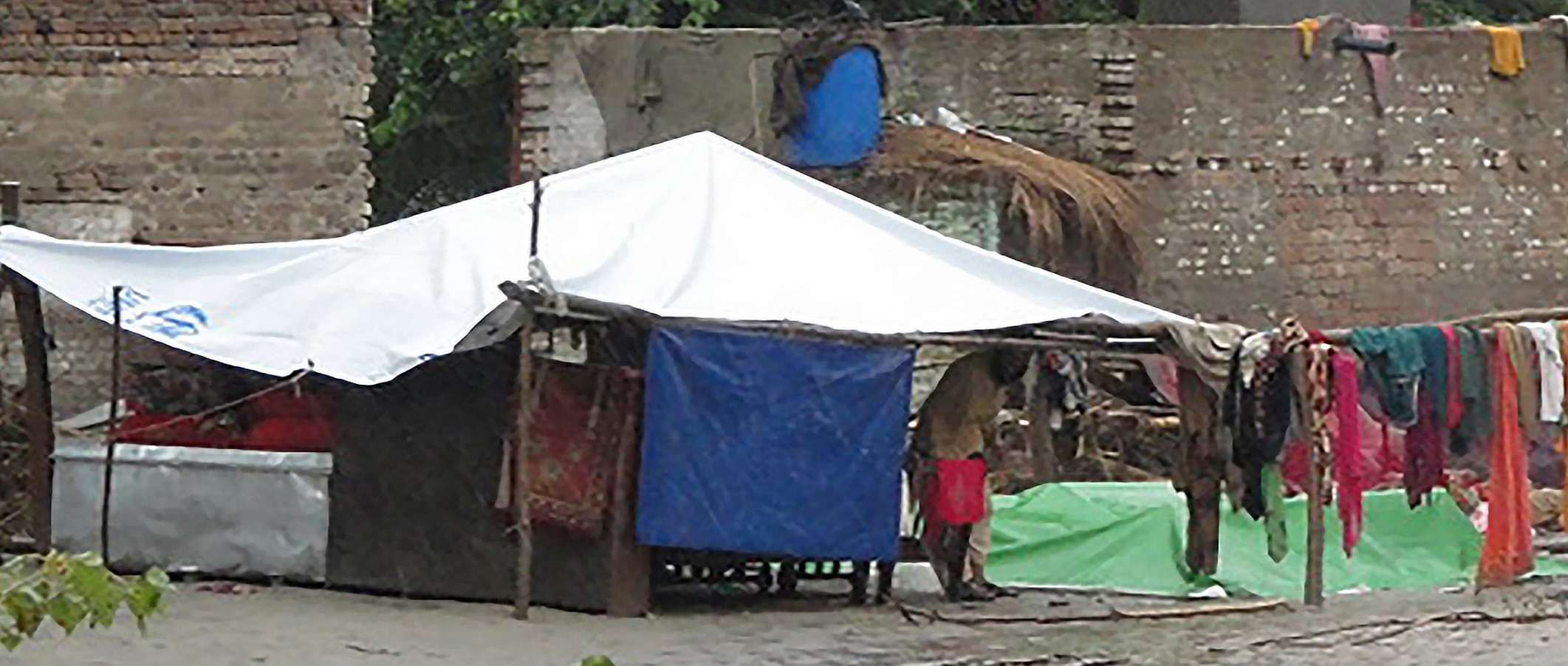

$x+3$

33

s.

4.

2.9. 